\title{
Intravitreal Triamcinolone
}

\author{
Yong Tao ${ }^{\mathrm{a}, \mathrm{b}}$ Jost B. Jonas ${ }^{\mathrm{a}}$ \\ ${ }^{a}$ Department of Ophthalmology, Medical Faculty Mannheim of the Ruprecht Karls University, Heidelberg,

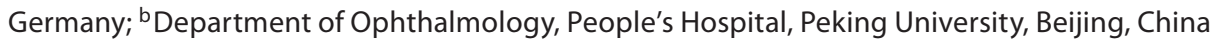

\section{Key Words}

Triamcinolone $\cdot$ Intraocular steroids - Diabetic retinopathy Macular edema - Retinal vein occlusion - Ocular hypotony • Ocular hypertension, steroid induced

\begin{abstract}
Background: To provide an update on the intravitreal use of triamcinolone acetonide. Methods: Review of literature regarding triamcinolone-related research. Results: After the introduction of bevacizumab and ranibizumab into clinical practice, intravitreal triamcinolone has lost its leading position as the drug most often injected intravitreally. Due to its properties as a long-acting steroid, triamcinolone has still been used for various conditions such as diffuse diabetic macular edema, retinal vein occlusions, pseudophakic cystoid macular edema, chronic prephthisical ocular hypotony and uveitis, and in combination with bevacizumab or ranibizumab. The complications of intravitreal triamcinolone therapy include secondary ocular hypertension in about $40 \%$ of the eyes injected, cataract and postoperative infectious or noninfectious endophthalmitis. Conclusions: Due to its widespread biological effects as a steroid and due to a relatively large therapeutic window, intravitreal triamcinolone has remained in clinical use for a variety of intraocular disorders, and it may be a promising candidate for intravitreal medical combination therapies.
\end{abstract}

Copyright $\odot 2010$ S. Karger AG, Basel

\section{Introduction}

It was Robert Machemer among others who suggested to use the vitreous cavity as a reservoir for drugs to directly treat intraocular diseases [1-12]. Robert Machemer and colleagues in particular thought about intravitreal triamcinolone acetonide (IVTA) as a therapy of proliferative vitreoretinopathy $[1,3,4,9,13-16]$. As a consequence of Machemer's suggestion, IVTA has been used for the treatment of other intraocular proliferative, edematous and neovascular diseases such as proliferative diabetic retinopathy $[17,18]$, diffuse diabetic macular edema (DME) and diabetic retinopathy in general [18-79], branch retinal vein occlusion (BRVO) [80-92], central retinal vein occlusion (CRVO) [93-111], neovascular glaucoma without or with cataract surgery [112-115], exudative age-related macular degeneration (AMD) [116152], myopic choroidal neovascularization [153, 154], presumed ocular histoplasmosis syndrome [155], chronic prephthisical ocular hypotony [156-158], chronic uveitis [159-168], persistent pseudophakic cystoid macular edema [169-174], sympathetic ophthalmia [175-177], radiation-induced macular edema [178, 179], immunologic corneal graft reaction [180], perifoveal telangiectasia [181-183], ischemic ophthalmopathy [184, 185], extensive exudative retinal detachment [186], and other disorders such as cystoid macular edema due to retinitis pigmentosa [187-189], endocrine orbitopathy [190], Vogt-Koy-

Dr. J. Jonas

Universitäts-Augenklinik

Theodor-Kutzer-Ufer 1-3, DE-68167 Mannheim (Germany)

Tel. +49621383 2242, Fax +496213833803

E-Mail Jost.Jonas@ augen.ma.uni-heidelberg.de
Fax +4161306 1234 E-Mail karger@karger.ch www.karger.com

\section{0-3755/11/2251-0001\$38.00/0}

Accessible online at:

www.karger.com/oph 
anagi-Harada syndrome [165] and others [191-206]. It has also been applied in combination with intraocular surgery to visualize the vitreous and for other reasons [207221].

The reasons for using a steroid for the treatment of intraocular edematous and proliferative diseases were that the abnormal proliferation of intraocular cells is often accompanied and stimulated by intraocular inflammation, and that besides the intraocular proliferation of cells, defects in the blood-retina barrier due to capillary leakage, with accumulation of fluid in the intraretinal and subretinal spaces of the macula, are other major causes of impaired vision. The reason for injecting the steroid into the eye was that corticosteroids applied topically as drops, given systemically or injected into the subconjunctival or sub-Tenon space, often did not reach a sufficiently high intraocular concentration to achieve a therapeutic level, or that the systemic side effects were too pronounced for prolonged treatment. The reason for using triamcinolone acetonide (TA) was that soluble substances injected into the eye usually leave the globe within hours to a few days $[6,222]$. In an attempt to achieve long-lasting concentrations of a drug, the drug may have to be used in a crystalline from or packed into a slow-release device $[6,36,40$, 222-225]. TA has been one of a few crystalline steroids available for clinical practice.

\section{The Compound: Physicochemical Characteristics}

TA is a synthetic steroid of the glucocorticoid family with a fluorine instead of a hydrogen atom in the ninth position [226]. The molecular weight of TA is 434.50 and its empirical formula is $\mathrm{C}_{24} \mathrm{H}_{31} \mathrm{FO}_{6}$ [227]. It is commercially available as an ester, a white powder only minimally soluble in water but soluble in alcohol and chloroform $[226,228]$. The current commercial preparations include Kenalog, Flutex, Kenacort-A, Kenaquart, Ledercort D, Oncilon-A, Respicort, Rineton, Solodelf, Tramacin, Tricinolon, Vetalog, Volonimat, and Aristocort acetonide [229].

The decreased water solubility accounts for its prolonged duration of action [228]. The elimination half-life of the commercial preparation of TA in vitreous humor of rat recently detected by Oishi et al. [230] was 6.08 days. In nonvitrectomized patient eyes, the mean elimination half-life was 18.6 days, while in 1 postvitrectomy patient eye, it decreased to 3.2 days [223]. After single intravitreal injection, peak aqueous humor concentrations ranged from 2.15 to $7.20 \mu \mathrm{g} / \mathrm{ml}$ [223]. Inoue et al. [40] found that the vitreous concentrations of TA after intravitreal injection were significantly higher than those after sub-Tenon injection $(1.22 \pm 0.24$ vs. $<0.001 \mu \mathrm{g} / \mathrm{ml}$; $\mathrm{p}=0.003)$.

\section{Preclinical (Animal) Studies}

IVTA has been applied in several preclinical studies [1, 3, 4, 8-10, 208, 210, 215, 216, 219]. Most animal studies did not show significant intraocular toxicity [5, 231-235]. As early as 1981, McCuen et al. [5] performed intravitreal injections of $1 \mathrm{mg}$ of TA into 1 eye of each of 21 rabbits, whereas the other eye received an injection of an equal volume of saline solution as a control. The results of slitlamp examinations, ophthalmoscopy, intraocular pressure, electroretinography and light electron microscopy all remained normal throughout the 3-month course of the experiment, demonstrating the lack of ocular toxicity of TA in the rabbit. Ruiz-Moreno et al. [233] demonstrated that up to $30 \mathrm{mg}$ of intravitreal TA did not seem to have acute toxic effects on the function (electroretinogram) or structure (electron and light microscopy) of the retina of albino rabbits at 28 days after IVTA injection.

IVTA has also been studied in particular conditions. Kivilcim et al. [235] performed IVTA injections at doses of 1,2 or $4 \mathrm{mg}$ in vitrectomized and silicone-filled rabbit eyes. The electroretinograms and histologic sections in all groups were normal, and no drug was visible in the vitreous cavity at the end of the 140-day period (average) in eyes injected with $4 \mathrm{mg}$ of TA.

\section{Clinical Studies: TA as Medical Device (Vitrectomy)}

In several studies, intraocular TA was used intraoperatively during pars plana vitrectomy to visualize the inner limiting membrane, epiretinal membranes and remnants of the vitreous base [207, 214, 219, 220, 236]. Yamamoto et al. [216] found that using TA during vitrectomy may facilitate both the removal of the epiretinal membrane around the macular hole and the separation of the residual vitreous cortex from the retina in highly myopic eyes with retinal detachment. Birinci [236] retrospectively reviewed the data on 72 patients (75 eyes) who accepted triamcinolone-assisted pars plana vitrectomy and cataract surgery for proliferative diabetic retinopathy. Postoperatively, visual acuity improved in 65 eyes (86.7\%) and complications consisted of mild iritis in 8 eyes $(10.7 \%)$, recurrent vitreous hemorrhage in 8 eyes 
(10.7\%), posterior capsule opacification in 7 eyes (9.3\%), transient intraocular pressure increase in 6 eyes $(8.0 \%)$, iatrogenic retinal tear in $6(8.0 \%)$ eyes and epiretinal membrane in 5 eyes (6.7\%). It was also reported that triamcinolone-assisted vitrectomy was tried by a 25 -gauge vitrectomy system and showed good results during 6 months of follow-up [237].

It may be of importance not to use IVTA in situations where the inner limiting membrane of the retina is removed since a study by Jaissle et al. [238] suggested that IVTA may exhibit a potentially cell-damaging effect if the limiting membrane is not present. It remains unclear whether the risk of a postoperative infectious endophthalmitis after triamcinolone-assisted vitrectomy is increased.

\section{Clinical Studies: TA as Drug Treatment for Macular Edema}

\section{Diabetic Macular Edema}

For decades, studies have suggested that IVTA may be useful to temporarily increase visual acuity in patients with diffuse DME $[18,19,21-34]$. The most convincing evidence came from a prospective, double-masked, placebo-controlled and randomized trial by Sutter et al. [34]. Eighteen of 33 eyes (55\%) treated with triamcinolone $(4 \mathrm{mg}$ ) gained 5 or more letters of best-corrected visual acuity compared with 5 of 32 eyes (16\%) treated with placebo $(p=0.002)$. Macular edema was reduced by 1 or more grades as determined by masked semiquantitative contact lens examination in 25 of 33 treated eyes (75\%) versus 5 of 32 untreated eyes (16\%; p < 0.0001).

Ciardella et al. [25] performed an intravitreal injection of $4 \mathrm{mg}$ of TA into 30 eyes of 22 consecutive patients with DME refractory to laser treatment. The mean visual acuity improved from $0.17 \pm 0.12$ at baseline to $0.31 \pm 0.17$, and the mean macular thickness measured by optical coherence tomography decreased from $476 \pm 98 \mu \mathrm{m}$ at baseline to $331 \pm 147 \mu \mathrm{m}$ at the 6 -month follow-up. A progressive reduction in the number and size of the hard exudates was noted after intravitreal TA in all patients. Similar results were reported in studies performed by $\mathrm{Mi}$ celli et al. [32], Karaçorlu et al. [28], Lee and Yang [30], Gharbiya et al. [196] and Negi et al. [45].

Larsson et al. [49] did not find a correlation between the improvement in visual acuity and the reduction in foveal thickness $(r=0.05 ; p=0.8)$ after a single intravitreal injection of $4 \mathrm{mg}$ of triamcinolone in DME. Correspondingly, a study looking for predictive factors for the change in visual acuity after IVTA injection found that the more marked the macular edema and the less marked the macular ischemia, the higher the increase in visual acuity after the injection [43]. The varying degree of macular ischemia may explain why some patients do not show a marked improvement in vision despite a regression of the macular edema and thickness. A multiple linear regression analysis revealed that improvement in visual acuity after IVTA injection was significantly correlated with a lower degree of macular ischemia $(p<0.001)$, higher preoperative visual acuity $(\mathrm{p}=0.002)$ and higher degree of macular edema.

The appropriate dose of IVTA for DME is a controversial topic. Both Hauser et al. [239] and Audren et al. [240] showed that the use of the higher 4-mg dose of IVTA does not have enough advantages over the lower 1- or 2-mg dose. However, Lam et al. [241] published a comparison between 4- and 8-mg doses and showed that the higher dose had a more sustained effect on both visual acuity and central macular thickness although with a trend to more ocular hypertensive responses. Using a dose of about $20 \mathrm{mg}$ of TA, the increase in visual acuity was most marked for the first 3-6 months after the injection, and was observable for a period of about 6-9 months [36]. Using a dose of $4 \mathrm{mg}$ of TA, the duration of the reduction in macular thickness as measured by optical coherence tomography was less than 6 months [31].

Several studies were performed to compare the efficacy and safety between IVTA and intravitreal bevacizumab [242], between IVTA and focal/grid photocoagulation [243-245], between IVTA plus photocoagulation and IVTA or photocoagulation alone [246], and between IVTA and vitrectomy with internal limiting membrane peeling [247]. In a randomized study, Avitabile et al. [53] compared the outcome after IVTA injection with macular laser grid photocoagulation for the treatment of cystoid macular edema due to diabetic retinopathy and retinal vein occlusion. After IVTA treatment, visual acuity significantly improved and the central macular thickness significantly decreased. In the macular grid laser study, visual acuity remained unchanged. The groups receiving triamcinolone had better visual acuity and lower central macular thickness values at all time points during followup. Recently, both the published 2-year [244] and 3-year [243] follow-up results of a randomized study by the DRCR.net (Diabetic Retinopathy Clinical Research Network) group did not indicate a benefit from IVTA relative to focal/grid photocoagulation in patients with DME. Moreover, Lam et al. [246] performed a randomized comparative study and found that combined treatment with 
IVTA plus grid laser did not yield a greater central macular thickness reduction or best-corrected visual acuity improvement at 6 months than IVTA alone. However, if IVTA and intravitreal bevacizumab were combined, a significantly greater macular thickness reduction in comparison with standard laser treatment was observed in another randomized study [248]. Recently, Kim et al. [247] showed that vitrectomy combined with inner limiting membrane removal had a better long-term efficacy than a single IVTA injection at 6 months after surgery. Shimura et al. [242] showed IVTA at a dose of $4 \mathrm{mg}$ was better at reducing DME and improving visual acuity than a dose of $1.25 \mathrm{mg}$ of bevacizumab within 6 months after injection. Nowadays, a multicenter, randomized and controlled trial (the TIME study) is in progress, which should be the first randomized prospective clinical trial to compare the effectiveness of IVTA with inner limiting membrane peeling [249].

So far, it has remained unclear whether and how intensively TA crystals injected into the vitreous body may influence the vitreoretinal interface. One may suspect that, due to their weight, the crystals may lead to a posterior vitreous detachment if the vitreous has not already been detached prior to the injection. A posterior vitreous detachment may have as a disadvantage the possibly increased risk of rhegmatogenous retinal detachment. So far, however, there have been no reports in the literature on a markedly elevated rate of retinal rhegmatogenous detachments as a complication in the follow-up of patients who received an IVTA injection [250]. The advantages of a posterior vitreous detachment in patients with diabetic retinopathy may be a reduction in macular edema, as suggested by studies on pars plana vitrectomy in patients with diffuse DME, and a decreased risk of retinovitreal proliferations.

\section{Branch Retinal Vein Occlusion}

In an exponentially increasing number of case series studies and nonrandomized comparative studies, IVTA has been used for the treatment of BRVO [80-92, 251]. Özkiris et al. [86] evaluated the efficacy of IVTA injection on persistent macular edema in BRVO that failed to respond to previous laser photocoagulation. During a mean follow-up time of $6.2 \pm 1.0$ months, the best-corrected logarithm of the minimal angle of resolution improved significantly $(\mathrm{p}<0.001)$ from $1.01 \pm 0.16$ at baseline to $0.62 \pm 0.22$ at the final follow-up.

Recently, there have been two reports $[252,253]$ from different departments showing an encouraging effect of IVTA combined with laser photocoagulation in eyes with macular edema after BRVO. In the report by Riese et al. [252], at 6 months after treatment, a gain of 1 or more logarithmic lines was achieved in $16 / 24$ eyes $(67 \%)$ and a gain of 3 lines or more was achieved in $8 / 24$ eyes (33\%), and the median central foveal thickness decreased from $423 \mu \mathrm{m}$ at baseline to $266 \mu \mathrm{m}(\mathrm{p}=0.001)$. Designed in a randomized way, Parodi et al. [253] compared the effectiveness of subthreshold grid laser treatment with infrared micropulse diode laser alone or in combination with IVTA for the treatment of macular edema secondary to BRVO. At the 12-month evaluation, 10 patients of the combination group (91\%) and 8 of the laser alone group (62\%) gained at least 10 letters (2 lines) in visual acuity. The mean number of lines gained was 3.4 and 1.3 in the combination group and in the laser alone group, respectively.

A recent randomized study compared the functional and anatomical outcomes of arteriovenous sheathotomy and IVTA for macular edema associated with BRVO. The between-group differences in average ETDRS (Early Treatment of Diabetic Retinopathy Study) score, total macular volume and foveal thickness changes were significantly better at 1 month after treatment in the IVTA group ( $\mathrm{p}=0.026, \mathrm{p}<0.001$ and $\mathrm{p}=0.001$, respectively), at which time IVTA patients had better vision and anatomical outcomes than those in the sheathotomy group [254].

All studies on IVTA for BRVO mentioned above have the serious flaw that they do not have a strict randomized design, and they often did not clearly differentiate between the nonischemic type and the ischemic type of the disease. Recently, the results of a multicenter and randomized clinical trial of 411 BRVO participants, the SCORE (Standard Care versus Corsticosteroid for Retinal Vein Occlusion) study, has been published [255]. There was no difference identified in visual acuity at 12 months for the standard care group (grid photocoagulation in eyes without dense macular hemorrhage, and deferral of photocoagulation until the hemorrhage clears in eyes with dense macular hemorrhage) compared with the triamcinolone groups; however, the rates of adverse events (particularly elevated intraocular pressure and cataract) were highest in the 4-mg group. Therefore, the authors recommended that grid photocoagulation should remain the benchmark against which other treatments are compared in clinical trials for eyes with vision loss associated with macular edema secondary to BRVO.

\section{Central Retinal Vein Occlusion}

After the first reports on the use of IVTA for the treatment of CRVO by Greenberg et al. [99] and Jonas et al. 
[104], the number of reports on the use of IVTA as therapy of CRVO have increased exponentially [93-111]. In a prospective nonrandomized comparative study on 11 eyes with CRVO receiving an intravitreal injection of TA, compared with 6 eyes of a control group without intravitreal injection of TA, the gain in visual acuity was significantly $(p=0.003)$ higher in the study group [103]. This confirms results of other reports on the beneficial effect of intravitreal TA on macular edema and visual acuity in patients with CRVO [81-99]. The results additionally suggest that the increase in visual acuity after IVTA injection may not last permanently in eyes with CRVO. After a significant increase in visual acuity in the first 3 months after the injection, visual acuity showed a tendency to decline towards the end of the follow-up. In a similar manner, Williamson and O'Donnell [111] found that intravitreal TA at a dose of $2 \mathrm{mg}$ was effective in reversing cystoid macular edema and improving visual acuity in recent-onset nonischemic CRVO in the first 6 months, but this was not sustained over the following 6 months.

Another positive effect of intravitreal TA in eyes with ischemic CRVO may be a direct or indirect antiangiogenic effect, possibly decreasing the risk of neovascularization [208, 256-266].

A recent nonrandomized comparative study [267] revealed that the therapeutic effects displayed no significant difference between the IVTA group and the intravitreal bevacizumab group with regard to visual results $(\mathrm{p}=$ $0.240)$ and macular thickness decrease $(\mathrm{p}=0.832)$, and IVTA seemed to cause more adverse events than bevacizumab, which was consistent with our own results [268].

Recently, the results of the SCORE study [269], a multicenter and randomized clinical trial of $271 \mathrm{CRVO}$ participants, showed that the odds of achieving a gain in visual acuity letter score of 15 or more from baseline to 12-month follow-up were 5.0 times greater in the 1-mg group than in the observation group $(\mathrm{p}=0.001)$, and 5.0 times greater in the 4-mg group than in the observation group ( $\mathrm{p}=0.001)$; there was no difference identified between the 1- and 4-mg groups ( $\mathrm{p}=0.97)$. The rates of elevated intraocular pressure and cataract were similar for the observation and 1-mg groups, but higher in the 4-mg group. The authors concluded that IVTA is superior to observation for treating vision loss associated with macular edema secondary to CRVO.

\section{Pseudophakic Cystoid Macular Edema}

Phacoemulsification with the implantation of an intraocular lens can be complicated by severe postoperative cystoid macular edema. The latter has usually been treated with topical, peribulbar and systemic applications of steroids or nonsteroidal antiinflammatory agents. Recently, IVTA has been used for the treatment of persisting pseudophakic cystoid macular edema [169-174]. Patients who developed cystoid macular edema after cataract surgery and who received an IVTA showed an increase in visual acuity from $0.26 \pm 0.13$ to a mean best visual acuity of $0.60 \pm 0.19$ [174]. There was no clear tendency suggesting a decrease in visual acuity towards the end of the follow-up period. The increase in visual acuity was statistically independent of the time interval between cataract surgery and IVTA treatment.

\section{Clinical Studies: TA for Proliferative Retinopathies}

\section{Pars Plana Vitrectomy for Proliferative Diabetic}

Vitreoretinopathy Combined with Intravitreal TA

Due to the antiinflammatory and antiangiogenic effects of TA, it was used in combination with pars plana vitrectomy in patients with proliferative diabetic retinopathy. A pilot case series study including 29 patients suggested that intravitreal injection of crystalline cortisone with most of the vehicle removed may be well tolerated [270]. A following nonrandomized comparative investigation consisted of 32 eyes undergoing pars plana vitrectomy with IVTA and 32 control eyes which were matched to the study eyes for preoperative and intraoperative parameters and underwent pars plana vitrectomy for proliferative diabetic retinopathy without IVTA [17]. The study and control eyes did not vary significantly in their rates of postoperative retinal detachment, repeated pars plana vitrectomy, postoperative enucleation and phthisis bulbi, and in their best postoperative visual acuity, visual acuity at the end of the study, and gain in visual acuity. Future randomized investigations may readdress the question whether adding intravitreal triamcinolone to pars plana vitrectomy may be helpful in the postoperative stabilization of the eye and in reducing the risk of postoperative cystoid macular edema and neovascularization.

\section{Pars Plana Vitrectomy for Proliferative}

Vitreoretinopathy Combined with Intravitreal TA

In a pilot study, IVTA was applied in combination with pars plana vitrectomy to the treatment of proliferative vitreoretinopathy [14]. During the follow-up period (mean: 1.64 months), intraocular inflammation and postoperative pain were significantly less severe in the 
study group. The study suggested that IVTA with most of the vehicle removed may not be toxic to intraocular structures, and that it reduces postoperative intraocular inflammation. In a following study, however, the redetachment rate was about $30 \%$ [16], so that up to now, IVTA has not generally been shown to be markedly useful in combination with pars plana vitrectomy for proliferative vitreoretinopathy. Enaida et al. [212] used TA in combination with pars plana vitrectomy and found that between the study group with TA ( $\mathrm{n}=94$ eyes) and the control group without TA ( $\mathrm{n}=83$ eyes), there were no significant differences in the frequency of improved vision after surgery, the rate of intraocular pressure higher than $21 \mathrm{~mm} \mathrm{Hg}$ after the operation, and the frequency of additional filtering surgeries. The study group had a slightly lower incidence of reoperations caused by preretinal fibrous membrane formation than the control group. Summarizing the clinical reports available, it remains unclear whether IVTA suppresses the proliferation of retinal pigment epithelium cells in vivo.

\section{Clinical Studies: TA in Other Ocular Diseases}

\section{Exudative AMD}

IVTA has been discussed to be a possibly useful adjunct to the therapy of exudative AMD [116-152] since previous studies had shown that TA may have an antiangiogenic and antiedematous effect $[112-115,258-260$, 262-266]. Both neovascularization and retinal edema are characteristics of exudative AMD.

Penfold et al. [116] were the first to inject TA intravitreally in an effort to treat exudative AMD medically. In 1998, Challa et al. [117] evaluated the safety and efficacy of IVTA after a follow-up of 18 months in patients with exudative AMD considered unsuitable for laser photocoagulation. In the nonrandomized clinical pilot study, 30 eyes of 28 patients were treated with an IVTA injection $(4 \mathrm{mg})$. Of the 20 eyes with initial visual acuity of 0.10 or better, vision was stabilized in 11 eyes (55\%), while 6 eyes (30\%) suffered severe visual loss (6 or more lines). Similar results of a possibly positive effect of IVTA on exudative AMD were reported in a randomized clinical trial by Danis et al. [118] and in other case series studies and nonrandomized comparative investigations $[119,121,125$, $126,128,135,152]$. One of these studies looked for factors influencing visual acuity after an intravitreal injection of TA as treatment of exudative AMD [126]. A postinjection increase in visual acuity was significantly $(\mathrm{p}<0.001)$ and negatively correlated with preoperative visual acuity, and it was significantly $(p=0.035)$ larger in eyes with retinal pigment epithelium detachment than in eyes with minimally classic subfoveal neovascularization. The effect of IVTA on visual acuity in patients with exudative AMD lasted about 6-8 months if a dose of about $20 \mathrm{mg}$ was used. If, after that time, visual acuity decreased again, some patients received a repeated injection of about 20 $\mathrm{mg}$ of TA followed by a reincrease in visual acuity [125].

The results of these nonrandomized studies are partly in contrast to those of a double-masked, placebo-controlled, randomized clinical study by Gillies et al. [123] which determined whether a single intravitreal injection of $4 \mathrm{mg}$ of TA can safely reduce the risk of severe visual loss in patients with classic choroidal neovascularization associated with AMD. The whole study population included 75 study eyes receiving IVTA and 76 control eyes without treatment. The development of a severe loss of vision of 30 or more letters by survival analysis on an intention-to-treat basis was the main outcome measure. Gillies et al. [123] did not find a significant difference between the two groups for the development of severe visual loss during the first year of the study. In both groups, the 12 -month risk of severe visual loss was $35 \%$. The change in size of the neovascular membranes, however, was significantly less in eyes receiving TA than in those receiving placebo 3 months after treatment although no difference was noted after 12 months. Although there were differences between the studies in the type of subfoveal neovascularization, the dosage of TA, and the timing of the follow-up examinations, the randomized controlled study by Gillies et al. [123] may be a landmark study cautioning against the use of TA as a monotherapy for exudative AMD. In agreement with Gillies et al. [123], a recent follow-up study on 205 patients who received IVTA as a monotherapy for the treatment of exudative AMD reported that visual acuity at 6,9 and 12 months after the injection was significantly $(\mathrm{p}<0.001)$ lower than visual acuity at the baseline of the study [136]. The mean loss at 6 months was $1.4 \pm 3.8$ Snellen lines, at 9 months it was $2.5 \pm 4.6$ lines, and at 12 months after the injection it was $2.6 \pm 4.0$ lines. It was concluded that a single highdose intravitreal triamcinolone injection may stabilize visual acuity in patients with neovascular AMD for about 3 months but may eventually be associated with a loss in visual acuity.

The studies mentioned above were the reason for initiating multicenter studies to evaluate the triamcinolone/ photodynamic therapy combined treatment: the VISTA trial led by Rick Spaide, the VERTACL trial led by Karl Csaky at the National Eye Institute, and a third trial fund- 
ed by a pharmaceutical company. Recent estimates suggest that about $70-90 \%$ of all verteporfin photodynamic treatments for exudative macular degeneration are combined with an intravitreal injection of TA.

In general, in the era of intravitreal use of bevacizumab for the treatment of exudative AMD, triamcinolone monotherapy seems to be no longer up to date.

Cataract Surgery on Eyes with Iris Neovascularization

In patients with dense cataract and iris neovascularization due to ischemic retinopathies, the lens opacification prevents a transpupillary laser coagulation of the retina. An intraocular intervention such as cataract surgery will, however, lead to a marked postoperative inflammation if iris neovascularization is additionally present. In that clinical situation, cataract surgery has been combined with IVTA [115]. In the postoperative period, visual acuity increased, and without additional retinal ablative treatments, the iris neovascularization markedly regressed within the first 5 weeks after surgery. The study suggested that IVTA may be a useful adjunctive treatment tool in eyes with iris neovascularization undergoing cataract surgery, and that IVTA may have an antiangiogenic effect.

\section{Uveitis}

Chronic uveitis has usually been treated by topical or systemic application of steroids. Topical treatment, however, often has not been sufficiently effective in suppressing intraocular inflammation and reducing cystoid macular edema. Systemic treatment with steroids inevitably leads to secondary side effects such as systemic suppression of the whole immune system and Cushing's syndrome. Based on the clinical experience gathered for the use of IVTA for other indications, TA has also been applied to eyes with chronic therapy-resistant uveitis [159168, 175-177, 197, 199, 200, 204, 271-275]. These diseases include Adamantiadis-Behçet's disease [199, 200]: Karaçorlu et al. [199] performed an intravitreal injection of TA $(4 \mathrm{mg})$ in 10 eyes of 10 patients with cystoid macular edema due to Behçet's disease. At the 1-, 3- and 6-month follow-ups, foveal thickness was significantly reduced. None of the eyes had lost vision at 1 month, and 8 eyes (80\%) showed improvement in visual acuity. At the 3-and 6-month follow-ups, 3 eyes (30\%) remained stable, and the other eyes had maintained the improved acuity. Kramer et al. [200] reported on 3 patients with acute severe exacerbations of noninfectious panuveitis and vitritis due to Adamantiadis-Behçet's disease who were treated with IVTA injections alone or as an adjunct to sys- temic immunosuppressive agents. They observed a rapid clearance of the vitreous inflammation with improvement in visual acuity $1-2$ weeks after injection. The effect lasted 2-6 months, with the shortest duration in a vitrectomized eye. Repeated injections were required in all patients.

Other diseases for which IVTA has been used are Eales' disease [204], the Vogt-Koyanagi-Harada syndrome [165], chronic sympathetic ophthalmia [175, 176] acute sympathetic ophthalmia [177], adult Coat's disease [197] and other diseases [168].

\section{Other Conditions}

IVTA has been applied as treatment for foveal telangiectasia. In two reports, IVTA increased visual acuity, while in a third report only 1 out of 2 patients experienced an increase in visual acuity $[181,182]$. Smithen and Spaide [183] reported a combined treatment of photodynamic therapy with verteporfin and IVTA injection (4 mg) for subfoveal neovascularization secondary to bilateral idiopathic juxtafoveal telangiectasias. Leakage in the late phase of fluorescein angiography resolved in an attenuation of telangiectatic vessels and an improvement in visual acuity from $20 / 200$ to $20 / 50$. At 9 months after treatment, recurrent leakage was treated with repeated photodynamic therapy and intravitreal triamcinolone. One year after initial presentation, visual acuity was $20 / 60$ with no leakage on fluorescein.

In a recent report on a patient presenting with longstanding cystoid macular edema after penetrating keratoplasty suggests that IVTA may be an additional tool in the treatment of longstanding therapy-resistant cystoid macular edema after intraocular surgery besides phacoemulsification [198]. The beneficial effects of triamcinolone-assisted vitrectomy during the management of retained nuclei by phacofragmentation were shown by Kaynak et al. [276]. An additional advantage of intraocular steroids to the treatment of cystoid macular edema after penetrating keratoplasty may be the suppression of an immunologic graft reaction as recently described [180, 277].

In contrast to ocular hypertension, which can often successfully be cured by a whole array of antiglaucomatous medical and surgical methods, progressive ocular hypotony can be an untreatable condition eventually leading to blindness and painful phthisis bulbi. In an attempt to use a side effect of steroids as a desired effect, TA was injected intravitreally in 3 eyes with longstanding prephthisical ocular hypotony [156]. In all 3 patients, intraocular pressure and visual acuity increased after the 
injection, associated with a stabilization of the eyes. This may suggest that in some eyes with longstanding prephthisical ocular hypotony, IVTA can be beneficial by increasing intraocular pressure and stabilizing the eye [156-158].

The antiangiogenic effect of TA was observed in an investigation of 14 eyes with neovascular glaucoma due to proliferative diabetic retinopathy or ischemic CRVO [113]. All patients received an intravitreal injection of about $20 \mathrm{mg}$ of acetonide as the only procedure $(\mathrm{n}=4$ eyes), or in combination with additional procedures such as goniosynechiolysis $(n=1)$ and transscleral peripheral retinal cryocoagulation. Postoperatively, the degree of iris neovascularization decreased significantly $(\mathrm{p}=0.02)$. Considering only the 4 patients for whom the intraocular cortisone injection was the only procedure performed, the mean intraocular pressure decreased from $26.5 \pm$ $12.1 \mathrm{~mm} \mathrm{Hg}$ to $21.75 \pm 11.3 \mathrm{~mm} \mathrm{Hg}$. This report on the possible use of IVTA for adjunct treatment of neovascular glaucoma has been supported by recent investigations $[112,114,115]$.

Further indications for which the intravitreal use of TA has been reported are ocular ischemic syndromes $[184,185]$, cystoid macular edema due to retinitis pigmentosa [187-189], radiation retinopathy $[178,179]$ and others [218].

\section{Adverse Events}

\section{Postinjection Infectious Endophthalmitis}

The frequency of postinjection infectious endophthalmitis as reported in recent studies ranged between 0/700 and 8/992 (0.87\%) [278-286]. The risk of an infectious endophthalmitis may partly depend on the setting of the injection itself. The studies suggest that if the injection is performed under sterile conditions, the risk of an infection may be less than if the injection is performed at the slit lamp without special precautions being taken.

Histologically, eyes with IVTA and infectious endophthalmitis show a marked destruction of the whole globe. The most striking finding can be that some areas show a massive infiltration by granulocytes, while other areas can be almost completely devoid of inflammatory cells [279]. Between both areas, there is a sharp demarcation line. It is the morphallaxia-like histology in which a dense infiltration by granulocytes is sharply demarcated by tissue areas in which inflammatory cells are almost completely missing. Such a histology, normally characteristic for the demarcation and destruction of necrotic anemic tissue as in the intrauterine resorption of a dead fetus, may be explained by the intraocular presence of high concentrations of TA. As a steroid, it may have inhibited the immigration of granulocytes into those areas in which the TA crystals are present. A morphallaxia-like histology is not commonly found in globes enucleated due to foudroyant infectious endophthalmitis, which is normally characterized by a marked destruction of all intraocular structures with a massive infiltration of all ocular structures by inflammatory cells. The morphallaxia-like morphology of infectious endophthalmitis in eyes with IVTA may be paralleled by the clinical observation that patients with infectious endophthalmitis after an IVTA injection usually show almost no pain, which is rather uncommon for infectious endophthalmitis in eyes without intraocular steroids [284]. The lack of inflammatory cells migrating into the eye may be the histologic correlate of the clinical observation [278-286].

With respect to susceptibility to infectious endophthalmitis, a recent experimental study showed that rabbit eyes with IVTA have a significantly higher rate of apparent intraocular infections than rabbits without IVTA if both groups were inoculated with Staphylococcus epidermidis organisms [287]. Concerning the multiple use of TA-containing bottles, another investigation showed that even after $24 \mathrm{~h}$ of exposure to a benzyl alcohol preservative, 4 of 5 challenge organisms demonstrated moderate growth in the bottle so that the use of multidose containers of triamcinolone for intravitreal injections was discouraged [288].

\section{Postinjection Pseudoendophthalmitis}

TA crystals can mimic a so-called pseudohypopyon if they penetrate from the vitreous cavity into the anterior chamber [14, 97, 173, 289-292]. The diagnostic problem is the differentiation between a painless hypopyon caused by a postinjection infectious endophthalmitis and a pseudohypopyon due to TA crystals. Using high-magnification slit-lamp biomicroscopy usually reveals the crystalline structure of TA. TA crystals in the anterior chamber usually disappear spontaneously and may not need to be removed. There have been no reports so far showing a corneal endothelial damage or damage to the trabecular meshwork by the crystals. If the intravitreal injection is performed in the direction of the center of the vitreous cavity, a pseudohypopyon may only rarely occur. If, however, the injection touches the posterior chamber, the TA crystals may not be trapped by the vitreous body but may partly be washed into the anterior chamber. 


\section{Secondary Ocular Hypertension, Secondary}

Steroid-Induced Open-Angle Glaucoma

One of the two most common side effects of IVTA is the steroid-induced elevation of intraocular pressure [106, 293-306]. A prospective clinical interventional comparative nonrandomized study included 260 consecutive patients (293 eyes) receiving an intravitreal injection of $20-25 \mathrm{mg}$ of TA as treatment for diffuse DME, exudative AMD, retinal vein occlusions, uveitis and cystoid macular edema [300]. Intraocular pressure readings higher than 21, 30, 35 and $40 \mathrm{~mm} \mathrm{Hg}$, respectively, were measured in 94 (36.2\%), 22 (8.5\%), 11 (4.2\%) and 4 (1.5\%) of the patients. The triamcinolone-induced elevation of intraocular pressure could be treated by antiglaucomatous medication in all but 3 eyes (1.0\%), for which filtering surgery became necessary. About $40 \%$ of the patients developed secondary ocular hypertension, starting about 1 week after the injection in a few eyes, and about 1-2 months after the intravitreal injection of 20-25 mg of TA in most eyes which had developed ocular hypertension. Using this dose, the increase in intraocular pressure lasted about 7-9 months, after which the intraocular pressure measurements returned to the normal range without any further antiglaucomatous medication taken. In a multiple regression analysis, younger age was a significant factor contributing to the TA-induced increase in intraocular pressure.

Unexpectedly, the postinjection rise in intraocular pressure did not vary significantly between patients with a preinjection diagnosis of chronic open-angle glaucoma and patients without a history of glaucoma. The reason for this unexpected finding has remained unclear so far. Either the number of patients in the glaucoma group was too small for a statistically significant difference between the two groups, or the preinjection antiglaucomatous treatment in the glaucoma group prevented a higher increase in intraocular pressure, or the megadose of 20-25 $\mathrm{mg}$ of intravitreally injected TA made baseline differences between the glaucoma group and the nonglaucomatous group disappear. If further studies confirm the finding, one may infer that, depending on the clinical situation and the severity of the macular disease, a diagnosis of chronic open-angle glaucoma may not be a major contraindication to IVTA.

The rise in intraocular pressure started at about 1 week after the injection, and the measurements returned to the baseline values after about 9 months. These figures are valid for a dose of about $20 \mathrm{mg}$ of TA. Although not systemically investigated in the present study, many eyes included in the investigation showed ophthalmoscopically visible TA crystals in the vitreous for as long as the increase in intraocular pressure lasted. This suggests that when the TA crystals have resolved, intraocular pressure may return to its baseline level, and that the triamcinolone-induced increase in intraocular pressure is reversible. It concurs with previous studies on the reaction of intraocular pressure after topical applications of corticosteroids [307].

Those patients who received a second injection of 20$25 \mathrm{mg}$ of TA showed a reaction of intraocular pressure similar to that after the first injection [300]. This suggests that if, after a first injection, the intraocular pressure remained within the normal range, it may also remain within the normal range after a second injection. In a similar manner, if the intraocular pressure increased after the first injection, a similar rise in intraocular pressure may be expected after a second injection.

Comparing studies using different doses of TA for intravitreal injection may suggest that the higher the dose, the longer the duration of steroid-induced ocular hypertension [106, 293-306]. If further studies confirm the assumption that the frequency of secondary ocular hypertension after an IVTA injection may not markedly depend on the dose used, one may assume that even relatively low TA doses are already high enough to occupy all steroid receptors. One has to take into account that the eye constitutes about $0.01 \%$ of the body volume. Assuming an equal distribution of TA throughout the body, an intravitreal injection of $4 \mathrm{mg}$ is equal to an intragluteal injection of $40 \mathrm{~g}$, and an intravitreal injection of $25 \mathrm{mg}$ of TA is equal to a quarter of a kilogram injected intragluteally.

\section{Rhegmatogenous Retinal Detachment}

Since TA is injected into the vitreous cavity, leading to a dearrangement of the structure of the vitreous body, and because an abnormal vitreous may exert traction on the retina, a potential complication of the intravitreal injection may be a rhegmatogenous retinal detachment. In a recent study on 348 eyes receiving an intravitreal injection of about $20 \mathrm{mg}$ of TA as treatment of exudative AMD, DME, retinal vein occlusions, persistent pseudophakic cystoid macular degeneration and uveitis, none of the eyes developed a rhegmatogenous retinal detachment or retinal lesions [308]. This held true in particular (1) for the inferior midperipheral area of the fundus where the TA crystals had settled in the preretinal vitreal cortex, (2) for the superior midperipheral and peripheral fundus where a vitreous traction might be induced by the weight of the TA crystals settled at 6 o'clock, and (3) for the far 
periphery of the fundus where retinal traction by the vitreous, if incarcerated into the injection site, might have resulted in reinjections $[299,309,310]$.

\section{Postinjection Steroid-Induced Cataract}

Besides secondary triamcinolone-induced ocular hypertension/temporary secondary open-angle glaucoma, cataract may be one of the two most common side effects of intravitreal triamcinolone $[298,311,312]$. In a recent study on 144 phakic eyes which consecutively received intravitreal injections of about $20 \mathrm{mg}$ of TA for diffuse DME, exudative AMD and BRVO, cataract surgery was performed on 20 eyes $(13.9 \%) 17.4 \pm 9.1$ months (median: 12.7 months; range: 8.0-35.5 months) after the intravitreal injection [312]. Out of the 20 eyes undergoing cataract surgery, 19 (95\%) had received 1 intravitreal injection, and 1 eye (5\%) had received 2 previous injections. It was concluded that in the elderly population of patients with exudative AMD, diffuse DME or BRVO, intravitreal high-dose injections of TA lead to clinically significant cataract with eventual cataract surgery in about 15 $20 \%$ of the eyes within about 1 year after the intravitreal injection. In an analysis of longitudinal data from a randomized, double-masked, placebo-controlled trial of intravitreal triamcinolone for AMD, Gillies et al. [298] compared 57 phakic eyes in the treatment group (4 mg TA) with 54 phakic eyes in the control group. They found that a progression of posterior subcapsular cataract by 2 or more grades in the treatment group occurred significantly more often among 16 intraocular pressure responders (51\% after 2 years) than among 37 nonresponders ( $3 \%$; $\mathrm{p}<0.0001)$. There was no significant progression of posterior subcapsular cataract in the placebo group or the opposite eyes of the treatment group. A progression of cortical cataracts also occurred significantly more often among responders than nonresponders ( $15 \mathrm{vs.}$ $3 \% ; \mathrm{p}=0.015)$. The percentage of progressions of nuclear cataracts (13 vs. $3 \%)$ was not significantly different between intraocular pressure responders and nonresponders $(\mathrm{p}=0.3)$. The authors concluded that, although steroid-related cataracts were unlikely to develop in eyes that do not experience an elevation of intraocular pressure after intravitreal triamcinolone, those eyes that do also have a very high risk of rapidly experiencing posterior subcapsular lens opacification. They postulated that this strong association suggests a similar mechanism responsible for the development of steroid-induced posterior subcapsular cataract and for the elevation of intraocular pressure. In a retrospective, interventional case-control study, Çekiç et al. [311] assessed cataract progression after intravitreal triamcinolone injections. They found that single intravitreal triamcinolone injections induced posterior subcapsular cataract development, whereas multiple injections resulted in all-layer cataract progression.

\section{Central Serous Chorioretinopathy}

Since steroids may be a risk factor for central serous chorioretinopathy, the question arises whether IVTA may lead to an increased frequency of central serous chorioretinopathy $[313,314]$. In a previous case report, a patient was described who developed central serous chorioretinopathy after vitrectomy with IVTA for DME [46]. It remained unclear whether it was a noncausal coincidence or whether the intravitreal steroid had led to the development of central serous chorioretinopathy. In another previous report on a patient who showed longstanding central serous chorioretinopathy continuously recurring for 6 years, an IVTA injection did not result in a resolution of the subfoveal accumulation of fluid, suggesting that on this type of macular disorder, IVTA may not have a therapeutically positive effect [195].

\section{Toxic Effects}

The intraocular use of Kenalog has not been approved by the FDA [229]. The preservative in Kenalog-40 is $0.99 \%$ benzyl alcohol [229], which may potentially be toxic to the retina and lens. A study by Kai et al. [315] investigated vehicle toxicity in New Zealand rabbits. In this study, TA with vehicle, either reduced or not, was injected into the vitreous cavity of rabbits. A significant increase in lens density and declining amplitudes of electroretinographic waves were observed in the vehicle-containing groups. Moreover, transmission electron microscopy showed that mitochondria of photoreceptors were swelling and ruptured in the vehicle-containing group compared with the control group; nevertheless, the reduced vehicle groups were normal. Similar results were observed in the reports by Macky et al. [316] report, in which pigmented rabbits were used, and by Lang et al. [317].

Direct toxic effects of TA on the retina and optic nerve have not yet been observed, independently of the dose used. Correspondingly, a recent safety and efficacy study of an intravitreal fluocinolone acetonide sustained-release delivery device used for the treatment of cystoid macular edema in patients with uveitis, as well as other clinical and experimental studies have not shown any toxic effect of intraocular steroids $[159,299]$. The same was found by Hida et al. [8] and Tokuda et al. [318]. It may be of importance that TA is usually not found in the se- 
rum shortly after its intravitreal application, suggesting that major systemic side effects may not be very probable [319].

However, recent studies conducted by Yeung et al. $[320,321]$ reported on a possible cytotoxic effect of TA. The authors found that TA caused a significant reduction in cell numbers throughout the whole range of concentrations when retinal pigment epithelium cells were exposed to it for more than 1 day. Compared with dexamethasone and hydrocortisone, TA showed the higher relative toxicity.

\section{Safety of IVTA Including High-Dose Reinjections}

In a case series study including 46 patients who received at least 2 intravitreal injections of about $20 \mathrm{mg}$ of TA for the treatment of diffuse DME, exudative AMD, secondary angle-closure glaucoma due to iris neovascularization, CRVO, BRVO, noninfectious uveitis, Coats' disease and exudative retinal detachment of unknown etiology [308], the second injection was carried out $6.7 \pm$ 3.4 months after the first, and 9 eyes received a third injection $8.0 \pm 4.6$ months after the second, 2 eyes received a fourth injection 9.5 and 10.8 months after the third, respectively, and 1 eye received 6 injections altogether. After all of these reinjections, no complications or side effects other than those already known to occur after a single IVTA were detected. After the first, second and third injections, intraocular pressure remained within the normal range in 24 (51\%), 25 (53\%) and 5 (56\%) eyes, respectively. Those eyes without a rise in intraocular pressure above $21 \mathrm{~mm} \mathrm{Hg}$ after the first injection did not show an elevation of intraocular pressure after a repeated injection. The mean maximal intraocular pressures after the first, second and third injections did not vary significantly ( $p>0.50)$. The results suggest (1) that intravitreal highdose reinjections may be tolerated by eyes within a mean follow-up of about 21 months after the first injection, or about 10 months after the last injection, (2) that the increase in intraocular pressure may not be more marked after a repeated injection than after the first injection, (3) and that side effects or complications may not occur more frequently after reinjections of TA than after a primary intravitreal high-dose injection.

\section{Discussion and Conclusions}

Intravitreal versus Sub-Tenon Application of TA

Several studies have addressed the question whether, instead of an intravitreal injection, a sub-Tenon injection could have the same results as an intravitreal injection by increasing visual acuity while avoiding the risks of an intraocular procedure $[60,88,131,322-324]$. Most of them agree that the sub-Tenon injection results in a lower intraocular concentration and a shorter duration of action compared with the intraocular injection. As one of the side effects of a sub-Tenon injection, ptosis and orbital fat prolapse have been reported [324].

\section{Purification of TA}

As already mentioned before, TA is not available without preservatives to date, and it remains unclear whether so-called sterile endophthalmitis may be associated with preservatives such as benzyl alcohol. Several techniques to remove the preservative have been described. All these methods have the disadvantage that the dose eventually ready for injection is too imprecise [63, 157, 325-327].

\section{Conclusions}

IVTA may open new avenues of treatment of intraocular edematous and neovascular diseases [328]. Since there have remained many open questions so far, the procedure may still be regarded as an experimental technique until randomized studies will eventually have proven the benefit of the therapy. The open issues include questions such as what may be the best dosage for which disease and for which clinical situation. In most studies on IVTA, a dose of $4 \mathrm{mg}$ has been used. In a few studies, a dose of about 20 $\mathrm{mg}$ of filtered TA has been used. Comparing the studies with each other may suggest that the frequency and severity of side effects may not be markedly different between the doses used, and that the duration of the side effects, particularly of secondary ocular hypertension, depends on the dose. Other unanswered questions are whether the proliferation of retinal pigment epithelium cells is hindered in high concentrations of TA and, paradoxically, furthered in low concentrations [329]. What is the best mode of application of TA? Is the sub-Tenon application, the subconjunctival application or the retrobulbar application better than the intravitreal injection? Are there other complications than those already described in clinical studies or after an accidental injection of TA into the vitreous cavity? Is it necessary to remove the solvent agent prior to the intraocular injection, and how should the solvent agent be removed? The most fascinating point may be that IVTA, together with previous clinical experiences of the use of intravitreal antibiotics and virustatic drugs, makes one understand that retinal diseases, par- 
ticularly macular disorders, become locally treatable diseases. Unbelievably high intraocular concentrations of drugs become achievable, and systemic side effects may mostly be avoided. Future directions may include the combined applications of IVTA with photodynamic therapy, possibly also with other intravitreal antiangiogenic medications, for the treatment of exudative AMD, and the intraocular application of TA in slow-release devices, possibly with a trigger mechanism to release the drug if necessary.

\section{References}

1 Machemer R, Sugita G, Tano Y: Treatment of intraocular proliferations with intravitreal steroids. Trans Am Ophthalmol Soc 1979;77: 171-180.

-2 Graham RO, Peyman GA: Intravitreal injection of dexamethasone: treatment of experimentally induced endophthalmitis. Arch Ophthalmol 1974;92:149-154.

- 3 Tano Y, Chandler D, Machemer R: Treatment of intraocular proliferation with intravitreal injection of triamcinolone acetonide. Am J Ophthalmol 1980;90:810-816.

-4 Tano Y, Sugita G, Abrams G, Machemer R: Inhibition of intraocular proliferations with intravitreal corticosteroids. Am J Ophthalmol 1980;89:131-136.

5 McCuen BW 2nd, Bessler M, Tano Y, Chandler D, Machemer R: The lack of toxicity of intravitreally administered triamcinolone acetonide. Am J Ophthalmol 1981;91:785788.

-6 Schindler RH, Chandler D, Thresher R, Machemer R: The clearance of intravitreal triamcinolone acetonide. Am J Ophthalmol 1982;93:415-417.

7 Ishibashi T, Miki K, Sorgente N, Patterson R, Ryan SJ: Effects of intravitreal administration of steroids on experimental subretinal neovascularization in the subhuman primate. Arch Ophthalmol 1985;103:708-711.

-8 Hida T, Chandler D, Arena JE, Machemer R: Experimental and clinical observations of the intraocular toxicity of commercial corticosteroid preparations. Am J Ophthalmol 1986;101:190-195.

$\checkmark 9$ Chandler DB, Hida T, Sheta S, Proia AD, Machemer R: Improvement in efficacy of corticosteroid therapy in an animal model of proliferative vitreoretinopathy by pretreatment. Graefes Arch Clin Exp Ophthalmol 1987; 225:259-265.

10 Coats ML, Peyman GA: Intravitreal corticosteroids in the treatment of exogenous fungal endophthalmitis. Retina 1992;12:46-51.

- 11 Antoszyk AN, Gottlieb JL, Machemer R, Hatchell DL: The effects of intravitreal triamcinolone acetonide on experimental preretinal neovascularization. Graefes Arch Clin Exp Ophthalmol 1993;231:34-40.

12 Machemer R: Five cases in which a depot steroid (hydrocortisone acetate and methylprednisolone acetate) was injected into the eye. Retina 1996;16:166-167.
13 Machemer R: Proliferative vitreoretinopathy (PVR): a personal account of its pathogenesis and treatment - proctor lecture. Invest Ophthalmol Vis Sci 1988;29:1771-1783.

14 Jonas JB, Hayler JK, Panda-Jonas S: Intravitreal injection of crystalline cortisone as adjunctive treatment of proliferative vitreoretinopathy. $\mathrm{Br}$ J Ophthalmol 2000;84: 1064-1067.

15 Furino C, Micelli Ferrari T, Boscia F, et al: Triamcinolone-assisted pars plana vitrectomy for proliferative vitreoretinopathy. Retina 2003;23:771-776.

16 Jonas JB, Sofker A, Hayler J, Degenring RF: Intravitreal crystalline triamcinolone acetonide as an additional tool in pars plana vitrectomy for complicated proliferative vitreoretinopathy? Acta Ophthalmol Scand 2003; 81:663-665.

17 Jonas JB, Sofker A, Degenring R: Intravitreal triamcinolone acetonide as an additional tool in pars plana vitrectomy for proliferative diabetic retinopathy. Eur J Ophthalmol 2003;13:468-473.

18 Bandello F, Pognuz DR, Pirracchio A, Polito A: Intravitreal triamcinolone acetonide for florid proliferative diabetic retinopathy. Graefes Arch Clin Exp Ophthalmol 2004; 242:1024-1027.

19 Jonas JB, Sofker A: Intraocular injection of crystalline cortisone as adjunctive treatment of diabetic macular edema. Am J Ophthalmol 2001;132:425-427.

20 Martidis A, Duker JS, Greenberg PB, et al: Intravitreal triamcinolone for refractory $\mathrm{di}$ abetic macular edema. Ophthalmology 2002;109:920-927.

21 Jonas JB, Kreissig I, Sofker A, Degenring RF: Intravitreal injection of triamcinolone for diffuse diabetic macular edema. Arch Ophthalmol 2003;121:57-61.

22 Audren F, Tod M, Massin P, et al: Pharmacokinetic-pharmacodynamic modeling of the effect of triamcinolone acetonide on central macular thickness in patients with diabetic macular edema. Invest Ophthalmol Vis Sci 2004;45:3435-3441.

23 Bakri SJ, Beer PM: Intravitreal triamcinolone injection for diabetic macular edema: a clinical and fluorescein angiographic case series. Can J Ophthalmol 2004;39:755-760.
24 Brooks HL Jr, Caballero S Jr, Newell CK, et al: Vitreous levels of vascular endothelial growth factor and stromal-derived factor 1 in patients with diabetic retinopathy and cystoid macular edema before and after intraocular injection of triamcinolone. Arch Ophthalmol 2004;122:1801-1807.

25 Ciardella AP, Klancnik J, Schiff W, et al: Intravitreal triamcinolone for the treatment of refractory diabetic macular oedema with hard exudates: an optical coherence tomography study. Br J Ophthalmol 2004;88:11311136.

26 Degenring RF, Kreissig I, Jonas JB: Intraocular triamcinolone for diffuse diabetic macular edema (in German). Ophthalmologe 2004;101:251-254.

27 Jonas JB, Harder B, Kamppeter BA: Inter-eye difference in diabetic macular edema after unilateral intravitreal injection of triamcinolone acetonide. Am J Ophthalmol 2004;138: 970-977.

28 Karaçorlu M, Özdemir H, Karaçorlu S, et al: Intravitreal triamcinolone as a primary therapy in diabetic macular oedema. Eye (Lond) 2005;19:382-386.

29 Karaçorlu M, Özdemir H, Karaçorlu S, Alacali N: Regression of optic nerve head neovascularization in proliferative diabetic retinopathy after intravitreal triamcinolone. Regression of diabetic optic disc neovascularization after intravitreal triamcinolone. Int Ophthalmol 2004;25:113-116.

30 Lee WF, Yang CM: Intravitreal triamcinolone injection for macular edema secondary to increased retinal vascular permeability. J Formos Med Assoc 2004;103:692-700.

31 Massin P, Audren F, Haouchine B, et al: Intravitreal triamcinolone acetonide for diabetic diffuse macular edema: preliminary results of a prospective controlled trial. Ophthalmology 2004;111:218-224, discussion 224-225.

32 Micelli Ferrari T, Sborgia L, Furino C, et al: Intravitreal triamcinolone acetonide: valuation of retinal thickness changes measured by optical coherence tomography in diffuse diabetic macular edema. Eur J Ophthalmol 2004;14:321-324.

33 Al-Haddad CE, Jurdi FA, Bashshur ZF: Intravitreal triamcinolone acetonide for the management of diabetic papillopathy. Am J Ophthalmol 2004;137:1151-1153. 
-34 Sutter FK, Simpson JM, Gillies MC: Intravitreal triamcinolone for diabetic macular edema that persists after laser treatment: threemonth efficacy and safety results of a prospective, randomized, double-masked, placebo-controlled clinical trial. Ophthalmology 2004;111:2044-2049.

- 35 Islam MS, Negi A, Vernon SA: Improved visual acuity and macular thickness 1 week after intravitreal triamcinolone for diabetic macular oedema. Eye (Lond) 2005;19:13251327.

- 36 Jonas JB, Degenring RF, Kamppeter BA, Kreissig I, Akkoyun I: Duration of the effect of intravitreal triamcinolone acetonide as treatment for diffuse diabetic macular edema. Am J Ophthalmol 2004;138:158-160.

-37 Lam DS, Chan CK, Tang EW, et al: Intravitreal triamcinolone for diabetic macular oedema in Chinese patients: six-month prospective longitudinal pilot study. Clin Experiment Ophthalmol 2004;32:569-572.

- 38 Özkiris A, Evereklioglu C, Öner A, Erkiliç K: Pattern electroretinogram for monitoring the efficacy of intravitreal triamcinolone injection in diabetic macular edema. Doc Ophthalmol 2004;109:139-145.

-39 Özkiris A, Evereklioglu C, Erkiliç K, Tamçelik N, Mirza E: Intravitreal triamcinolone acetonide injection as primary treatment for diabetic macular edema. Eur J Ophthalmol 2004:14:543-549.

-40 Inoue M, Takeda K, Morita K, et al: Vitreous concentrations of triamcinolone acetonide in human eyes after intravitreal or subtenon injection. Am J Ophthalmol 2004;138:10461048.

41 Jonas JB, Kreissig I, Degenring RF, Kamppeter BA: Repeated intravitreal injection of triamcinolone acetonide for diffuse diabetic macular oedema. Br J Ophthalmol 2005;89: 122.

42 Jonas JB, Akkoyun I, Kreissig I, Degenring RF: Diffuse diabetic macular oedema treated by intravitreal triamcinolone acetonide: a comparative, non-randomised study. Br J Ophthalmol 2005;89:321-326.

-43 Jonas JB, Martus P, Degenring RF, Kreissig I, Akkoyun I: Predictive factors for visual acuity after intravitreal triamcinolone treatment for diabetic macular edema. Arch Ophthalmol 2005;123:1338-1343.

44 Gupta R, Negi A, Vernon SA: Severe subconjunctival haemorrhage following intravitreal triamcinolone for refractory diabetic oedema. Eye (Lond) 2005;19:590-591.

-45 Negi AK, Vernon SA, Lim CS, Owen-Armstrong $\mathrm{K}$ : Intravitreal triamcinolone improves vision in eyes with chronic diabetic macular oedema refractory to laser photocoagulation. Eye (Lond) 2005;19:747-751.

- 46 Imasawa M, Ohshiro T, Gotoh T, Imai M, Iijima $\mathrm{H}$ : Central serous chorioretinopathy following vitrectomy with intravitreal triamcinolone acetonide for diabetic macular oedema. Acta Ophthalmol Scand 2005;83: 132-133.
47 Krepler K, Wagner J, Sacu S, Wedrich A: The effect of intravitreal triamcinolone on diabetic macular oedema. Graefes Arch Clin Exp Ophthalmol 2005;243:478-481.

48 Lam DS, Chan CK, Mohamed S, et al: Phacoemulsification with intravitreal triamcinolone in patients with cataract and coexisting diabetic macular oedema: a 6-month prospective pilot study. Eye (Lond) 2005;19: 885-890.

49 Larsson J, Zhu M, Sutter F, Gillies MC: Relation between reduction of foveal thickness and visual acuity in diabetic macular edema treated with intravitreal triamcinolone. Am J Ophthalmol 2005;139:802-806.

50 Zacks DN, Johnson MW: Combined intravitreal injection of triamcinolone acetonide and panretinal photocoagulation for concomitant diabetic macular edema and proliferative diabetic retinopathy. Retina 2005;25: 135-140.

51 Flynn HW Jr, Scott IU: Intravitreal triamcinolone acetonide for macular edema associated with diabetic retinopathy and venous occlusive disease: it's time for clinical trials. Arch Ophthalmol 2005;123:258-259.

52 Er H, Yilmaz H: Intravitreal cortisone injection for refractory diffuse diabetic macular edema. Ophthalmologica 2005;219:394400.

53 Avitabile T, Longo A, Reibaldi A: Intravitreal triamcinolone compared with macular laser grid photocoagulation for the treatment of cystoid macular edema. Am J Ophthalmol 2005; 140:695-702.

54 Ladjimi A, Zeghidi H, Ben Yahia S, et al: Intravitreal injection of triamcinolone acetonide for the treatment of macular edema (in French). J Fr Ophtalmol 2005;28:749-757.

55 Patelli F, Fasolino G, Radice P, et al: Time course of changes in retinal thickness and visual acuity after intravitreal triamcinolone acetonide for diffuse diabetic macular edema with and without previous macular laser treatment. Retina 2005;25:840-845.

-56 Khairallah M, Zeghidi H, Ladjimi A, et al: Primary intravitreal triamcinolone acetonide for diabetic massive macular hard exudates. Retina 2005;25:835-839.

57 Chieh JJ, Roth DB, Liu M, et al: Intravitreal triamcinolone acetonide for diabetic macular edema. Retina 2005;25:828-834.

58 Tewari HK, Sony P, Chawla R, Garg SP, Venkatesh P: Prospective evaluation of intravitreal triamcinolone acetonide injection in macular edema associated with retinal vascular disorders. Eur J Ophthalmol 2005;15: 619-626.

59 Gibran SK, Cullinane A, Jungkim S, Cleary PE: Intravitreal triamcinolone for diffuse diabetic macular oedema. Eye (Lond) 2006;20: $720-724$.
60 Cardillo JA, Melo LA Jr, Costa RA, et al: Comparison of intravitreal versus posterior sub-Tenon's capsule injection of triamcinolone acetonide for diffuse diabetic macular edema. Ophthalmology 2005; 112:15571563.

61 Özdemir H, Karaçorlu M, Karaçorlu SA: Regression of serous macular detachment after intravitreal triamcinolone acetonide in patients with diabetic macular edema. Am J Ophthalmol 2005;140:251-255.

62 Sørensen TL, Haamann P, Villumsen J, Larsen M: Intravitreal triamcinolone for macular oedema: efficacy in relation to aetiology. Acta Ophthalmol Scand 2005;83:67-70.

-63 Spandau UH, Derse M, Schmitz-Valckenberg P, Papoulis C, Jonas JB: Dosage dependency of intravitreal triamcinolone acetonide as treatment for diabetic macular oedema. Br J Ophthalmol 2005;89:999-1003.

64 Nicolo M, Nasciuti F, Lai S, et al: Intravitreal triamcinolone acetonide as primary treatment for diffuse diabetic macular edema: a prospective noncomparative interventional case series. Eur J Ophthalmol 2006;16:129133.

65 Jonas JB, Kamppeter BA, Harder B, et al: Intravitreal triamcinolone acetonide for diabetic macular edema: a prospective, randomized study. J Ocul Pharmacol Ther 2006; 22:200-207.

66 Jonas JB, Spandau UH, Kamppeter BA, et al: Repeated intravitreal high-dosage injections of triamcinolone acetonide for diffuse diabetic macular edema. Ophthalmology 2006; 113:800-804

67 Desatnik H, Habot-Wilner Z, Alhalel A, et al: The transient efficacy of a single intravitreal triamcinolone acetonide injection for diabetic macular edema. Isr Med Assoc J 2006; 8:383-387.

68 Gillies MC, Sutter FK, Simpson JM, et al: Intravitreal triamcinolone for refractory diabetic macular edema: two-year results of a double-masked, placebo-controlled, randomized clinical trial. Ophthalmology 2006; 113:1533-1538.

69 Jonas JB, Spandau UH, Kamppeter BA, Vossmerbauemer U, Harder B: Follow-up after intravitreal triamcinolone acetonide for diabetic macular edema. Eur J Ophthalmol 2006;16:566-572.

-70 Ramezani A, Ahmadieh H, Tabatabaei H: Intravitreal triamcinolone reinjection for refractory diabetic macular edema. Korean J Ophthalmol 2006;20:156-161.

-71 Selim Kocabora M, Küçüksahin H, Gülkilik G, et al: Treatment of diabetic macular edema with intravitreal triamcinolone acetonide injection: functional and anatomical outcomes (in French). J Fr Ophtalmol 2007;30: 32-38.

72 Batioglu F, Özmert E, Parmak N, Çelik S: Two-year results of intravitreal triamcinolone acetonide injection for the treatment of diabetic macular edema. Int Ophthalmol 2007;27:299-306 
73 Pinheiro A, Serracarbassa PD, Maia OO Jr, Takahashi WY: Macular thickness analysis by optic coherence tomography in refractory diabetic macular edema treated with intravitreous triamcinolone (in Portuguese). Arq Bras Oftalmol 2007;70:784-789.

74 Bardak Y, Çekiç O, Sahin Tig U, Bardak H: Alterations in central retinal sensitivity after intravitreal triamcinolone injection for diffuse diabetic macular edema. Eur J Ophthalmol 2007;17:780-784.

75 Dusová J, Studnicka J, Rencová E, Korda V, Hejcmanová D: Triamcinolone in the treatment of the diabetic macular edema: oneyear results (in Czech). Cesk Slov Oftalmol 2008;64:149-152.

76 Dehghan MH, Ahmadieh H, Ramezani A, Entezari M, Anisian A: A randomized, placebo-controlled clinical trial of intravitreal triamcinolone for refractory diabetic macular edema. Int Ophthalmol 2008;28:7-17.

-77 Karaçorlu M, Özdemir H, Sentürk F, Arf Karaçorlu S, Uysal O: Macular function by multifocal electroretinogram in diabetic macular edema after intravitreal triamcinolone acetonide injection. Eur J Ophthalmol 2008; 18:601-608

78 Wickremasinghe SS, Rogers SL, Gillies MC, Zhu M, Wong TY: Retinal vascular caliber changes after intravitreal triamcinolone treatment for diabetic macular edema. Invest Ophthalmol Vis Sci 2008;49:4707-4711.

-79 Çekiç O, Bardak Y, Tig US, Yildizoglu U, Bardak H: Quantitative evaluation of reduction of plaque-like hard exudates in diabetic macular edema after intravitreal triamcinolone injection. Int Ophthalmol 2008;28:9599.

80 Chen SD, Lochhead J, Patel CK, Frith P: Intravitreal triamcinolone acetonide for ischaemic macular oedema caused by branch retinal vein occlusion. $\mathrm{Br} \mathrm{J}$ Ophthalmol 2004;88:154-155.

-81 Jonas JB, Akkoyun I, Kamppeter B, Kreissig I, Degenring RF: Branch retinal vein occlusion treated by intravitreal triamcinolone acetonide. Eye (Lond) 2005;19:65-71.

-82 Tsujikawa A, Fujihara M, Iwawaki T, Yamamoto K, Kurimoto Y: Triamcinolone acetonide with vitrectomy for treatment of macular edema associated with branch retinal vein occlusion. Retina 2005;25:861-867.

83 Çekiç O, Chang S, Tseng JJ, et al: Intravitreal triamcinolone injection for treatment of macular edema secondary to branch retinal vein occlusion. Retina 2005;25:851-855.

84 Karaçorlu M, Özdemir H, Karaçorlu SA: Resolution of serous macular detachment after intravitreal triamcinolone acetonide treatment of patients with branch retinal vein occlusion. Retina 2005;25:856-860.

-85 Özkiris A, Evereklioglu C, Erkiliç K, Dogan $\mathrm{H}$ : Intravitreal triamcinolone acetonide for treatment of persistent macular oedema in branch retinal vein occlusion. Eye (Lond) 2006;20:13-17.
86 Özkiris A, Evereklioglu C, Erkiliç K, Ilhan O: The efficacy of intravitreal triamcinolone acetonide on macular edema in branch retinal vein occlusion. Eur J Ophthalmol 2005; 15:96-101

87 Krepler K, Ergün E, Saçu S, et al: Intravitreal triamcinolone acetonide in patients with macular oedema due to branch retinal vein occlusion: a pilot study. Acta Ophthalmol Scand 2005;83:600-604.

$>88$ Hayashi K, Hayashi H: Intravitreal versus retrobulbar injections of triamcinolone for macular edema associated with branch retinal vein occlusion. Am J Ophthalmol 2005; 139:972-982.

89 Kaiser PK: Steroids for branch retinal vein occlusion. Am J Ophthalmol 2005;139:10951096.

90 Lee H, Shah GK: Intravitreal triamcinolone as primary treatment of cystoid macular edema secondary to branch retinal vein occlusion. Retina 2005;25:551-555.

91 Salinas-Alamán A, García-Layana A, Sádaba-Echarri LM, Belzunce-Manterola A: Branch retinal vein occlusion treated by in travitreal triamcinolone (in Spanish). Arch Soc Esp Oftalmol 2005;80:463-465.

92 Yepremyan M, Wertz FD, Tivnan T, Eversman L, Marx JL: Early treatment of cystoid macular edema secondary to branch retinal vein occlusion with intravitreal triamcinolone acetonide. Ophthalmic Surg Lasers Imaging 2005;36:30-36.

93 Bashshur ZF, Ma'luf RN, Allam S, et al: In travitreal triamcinolone for the management of macular edema due to nonischemic central retinal vein occlusion. Arch Ophthalmol 2004; 122:1137-1140.

94 Bynoe LA, Weiss JN: Retinal endovascular surgery and intravitreal triamcinolone acetonide for central vein occlusion in young adults. Am J Ophthalmol 2003;135:382-384.

$>95$ Çekiç O, Chang S, Tseng JJ, et al: Intravitreal triamcinolone treatment for macular edema associated with central retinal vein occlusion and hemiretinal vein occlusion. Retina 2005; 25:846-850.

$\checkmark 96$ Chen SD, Lochhead J, Satchi K, Patel CK, Frith P: Bilateral retinal venous occlusion and unilateral cystoid macular edema in Churg-Strauss syndrome treated with intravitreal triamcinolone. Retina 2005;25:655657.

97 Chiu YT, Tsai YY, Lin JM: Noninfectious hypopyon after intravitreal triamcinolone acetonide injection for central retinal vein occlusion: a case report. Kaohsiung J Med Sci 2005;21:466-469.

98 Degenring RF, Kamppeter B, Kreissig I, Jonas JB: Morphological and functional changes after intravitreal triamcinolone acetonide for retinal vein occlusion. Acta Ophthalmol Scand 2003;81:399-401.
$\$ 99$ Greenberg PB, Martidis A, Rogers AH, Duker JS, Reichel E: Intravitreal triamcinolone acetonide for macular oedema due to central retinal vein occlusion. Br J Ophthalmol 2002;86:247-248.

100 Ip M, Kahana A, Altaweel M: Treatment of central retinal vein occlusion with triamcinolone acetonide: an optical coherence tomography study. Semin Ophthalmol 2003; 18:67-73.

101 Ip MS, Gottlieb JL, Kahana A, et al: Intravitreal triamcinolone for the treatment of macular edema associated with central retinal vein occlusion. Arch Ophthalmol 2004;122:1131-1136.

102 Ip MS, Kumar KS: Intravitreous triamcinolone acetonide as treatment for macular edema from central retinal vein occlusion. Arch Ophthalmol 2002;120:1217-1219.

103 Jonas JB, Akkoyun I, Kamppeter B, Kreissig I, Degenring RF: Intravitreal triamcinolone acetonide for treatment of central retinal vein occlusion. Eur J Ophthalmol 2005;15: 751-758.

104 Jonas JB, Kreissig I, Degenring RF: Intravitreal triamcinolone acetonide as treatment of macular edema in central retinal vein occlusion. Graefes Arch Clin Exp Ophthalmol 2002;240:782-783.

105 Karaçorlu M, Özdemir H, Karaçorlu S: Intravitreal triamcinolone acetonide for the treatment of central retinal vein occlusion in young patients. Retina 2004;24:324-327.

106 Kaushik S, Gupta V, Gupta A, Dogra MR, Singh R: Intractable glaucoma following intravitreal triamcinolone in central retinal vein occlusion. Am J Ophthalmol 2004;137: 758-760.

107 Krepler K, Ergün E, Saçu S, et al: Intravitreal triamcinolone acetonide in patients with macular oedema due to central retinal vein occlusion. Acta Ophthalmol Scand 2005;83:71-75.

108 Park CH, Jaffe GJ, Fekrat S: Intravitreal triamcinolone acetonide in eyes with cystoid macular edema associated with central retinal vein occlusion. Am J Ophthalmol 2003; 136:419-425

109 Scott IU, Ip MS: It's time for a clinical trial to investigate intravitreal triamcinolone for macular edema due to retinal vein occlusion: the SCORE study. Arch Ophthalmol 2005;123:581-582.

110 Wakabayashi T, Okada AA, Morimura Y, et al: Trans-Tenon retrobulbar triamcinolone infusion for chronic macular edema in central and branch retinal vein occlusion. Retina 2004;24:964-967.

111 Williamson TH, O’Donnell A: Intravitreal triamcinolone acetonide for cystoid macular edema in nonischemic central retinal vein occlusion. Am J Ophthalmol 2005; 139 : $860-866$.

-112 Bonanomi MT, Susanna R Jr: Intravitreal triamcinolone acetonide as adjunctive treatment for neovascular glaucoma. Clinics 2005;60:347-350. 
113 Jonas JB, Hayler JK, Sofker A, Panda-Jonas $\mathrm{S}$ : Regression of neovascular iris vessels by intravitreal injection of crystalline cortisone. J Glaucoma 2001;10:284-287.

114 Jonas JB, Kreissig I, Degenring RF: Neovascular glaucoma treated by intravitreal triamcinolone acetonide. Acta Ophthalmol Scand 2003;81:540-541.

115 Jonas JB, Sofker A: Intravitreal triamcinolone acetonide for cataract surgery with iris neovascularization. J Cataract Refract Surg 2002;28:2040-2041.

-116 Penfold PL, Gyory JF, Hunyor AB, Billson FA: Exudative macular degeneration and intravitreal triamcinolone: a pilot study. Aust NZ J Ophthalmol 1995;23:293-298.

-117 Challa JK, Gillies MC, Penfold PL, et al: Exudative macular degeneration and intravitreal triamcinolone: 18-month follow-up. Aust NZ J Ophthalmol 1998;26:277-281.

-118 Danis RP, Ciulla TA, Pratt LM, Anliker W: Intravitreal triamcinolone acetonide in exudative age-related macular degeneration. Retina 2000;20:244-250.

-119 Jonas JB, Kreissig I, Degenring R: Repeated intravitreal injections of triamcinolone acetonide as treatment of progressive exudative age-related macular degeneration. Graefes Arch Clin Exp Ophthalmol 2002; 240:873-874.

120 Penfold PL: Intravitreal triamcinolone in recurrence of choroidal neovascularisation. Br J Ophthalmol 2002;86:600-601.

-121 Jonas JB, Kreissig I, Hugger P, et al: Intravitreal triamcinolone acetonide for exudative age-related macular degeneration. Br J Ophthalmol 2003;87:462-468.

-122 Ranson NT, Danis RP, Ciulla TA, Pratt L: Intravitreal triamcinolone in subfoveal recurrence of choroidal neovascularisation after laser treatment in macular degeneration. Br J Ophthalmol 2002;86:527-529.

123 Gillies MC, Simpson JM, Luo W, et al: A randomized clinical trial of a single dose of intravitreal triamcinolone acetonide for neovascular age-related macular degeneration: one-year results. Arch Ophthalmol 2003;121:667-673.

124 Spaide RF, Sørenson J, Maranan L: Combined photodynamic therapy with verteporfin and intravitreal triamcinolone acetonide for choroidal neovascularization. Ophthalmology 2003;110:1517-1525.

- 125 Jonas JB, Akkoyun I, Budde WM, Kreissig I, Degenring RF: Intravitreal reinjection of triamcinolone for exudative age-related macular degeneration. Arch Ophthalmol 2004; 122:218-222.

$>126$ Jonas JB, Kreissig I, Degenring RF: Factors influencing visual acuity after intravitreal triamcinolone acetonide as treatment of exudative age-related macular degeneration. Br J Ophthalmol 2004;88:1557-1562.
127 Rechtman E, Danis RP, Pratt LM, Harris A: Intravitreal triamcinolone with photodynamic therapy for subfoveal choroidal neovascularisation in age-related macular degeneration. Br J Ophthalmol 2004;88: 344-347.

128 Jonas JB, Degenring RF, Kreissig I, Friedemann T, Akkoyun I: Exudative age-related macular degeneration treated by intravitreal triamcinolone acetonide: a prospective comparative nonrandomized study. Eye (Lond) 2005;19:163-170.

129 Arévalo JF, García RA, Mendoza AJ: Indocyanine-green-mediated photothrombosis with intravitreal triamcinolone acetonide for subfoveal choroidal neovascularization in age-related macular degeneration. Graefes Arch Clin Exp Ophthalmol 2005;243: 1180-1185.

130 Deckers V, Priem H, Verbraeken H: One year of intravitreal injections of steroids. Bull Soc Belge Ophtalmol 2005:69-77.

131 van de Moere A, Sandhu SS, Kak R Mitchell KW, Talks SJ: Effect of posterior juxtascleral triamcinolone acetonide on choroidal neovascular growth after photodynamic therapy with verteporfin. Ophthalmology 2005;112:1896-1903.

132 Spaide RF, Sørenson J, Maranan L: Combined photodynamic therapy and intravitreal triamcinolone for nonsubfoveal choroidal neovascularization. Retina 2005;25: 685-690.

133 Spaide RF, Sørenson J, Maranan L: Photodynamic therapy with verteporfin combined with intravitreal injection of triamcinolone acetonide for choroidal neovascularization. Ophthalmology 2005; 112:301-304.

134 Larsson J, Gillies MC: Severe loss of vision after removal of cataract caused by intravitreal triamcinolone in combination with photodynamic therapy for exudative agerelated macular degeneration. Clin Experiment Ophthalmol 2005;33:544-545.

135 Nicolo M, Ghiglione D, Lai S, Calabria G: Intravitreal triamcinolone in the treatment of serous pigment epithelial detachment and occult choroidal neovascularization secondary to age-related macular degeneration. Eur J Ophthalmol 2005;15:415-419.

136 Jonas JB, Spandau UH, Kamppeter BA, Harder B: Follow-up after intravitreal triamcinolone acetonide for exudative agerelated macular degeneration. Eye (Lond) 2007;21:387-394

137 Augustin AJ, Schmidt-Erfurth U: Verteporfin therapy combined with intravitreal triamcinolone in all types of choroidal neovascularization due to age-related macular degeneration. Ophthalmology 2006;113: 14-22.
138 Augustin AJ, Schmidt-Erfurth U: Verteporfin and intravitreal triamcinolone acetonide combination therapy for occult choroidal neovascularization in age-related macular degeneration. Am J Ophthalmol 2006;141:638-645.

139 Jonas JB, Strueven V, Kamppeter BA, et al: Visual acuity change after intravitreal triamcinolone in various types of exudative age-related macular degeneration. J Ocul Pharmacol Ther 2006;22:370-376.

140 Ito M, Okubo A, Sonoda Y, Yamakiri K, Sakamoto T: Intravitreal triamcinolone acetonide for exudative age-related macular degeneration among Japanese patients. Ophthalmologica 2006;220:118-124.

141 Lee J, Freeman WR, Azen SP, Chung EJ, Koh HJ: Prospective, randomized clinical trial of intravitreal triamcinolone treatment of neovascular age-related macular degeneration: one-year results. Retina 2007;27:1205-1213.

142 Lubinski W, Gosławski W, Mozolewska-Piotrowska K, Szych Z, Karczewicz D: Evaluation of visual function among patients with exudative AMD treated with an intravitreal injection of triamcinolone acetonide (in Polish). Ann Acad Med Stetin 2008;54: 22-27, discussion 27.

143 Ruiz-Moreno JM, Montero JA, Barile S, Zarbin MA: Photodynamic therapy and high-dose intravitreal triamcinolone to treat exudative age-related macular degeneration: 1-year outcome. Retina 2006;26: 602-612.

144 Ruiz-Moreno JM, Montero JA, Zarbin MA: Photodynamic therapy and high-dose intravitreal triamcinolone to treat exudative age-related macular degeneration: 2-year outcome. Retina 2007;27:458-461.

145 Leparmentier A, Arnaud C, Fournié P, Mathis A, Quintyn JC: Combined photodynamic therapy with verteporfin and intravitreal triamcinolone acetonide for choroidal neovascularization with pigment epithelium detachment in age-related macular degeneration (in French). J Fr Ophtalmol 2007;30:155-160.

146 Kumar A, Sinha S, Kumar V: Visual acuity and contrast sensitivity outcomes in Indian eyes undergoing photodynamic therapy with intravitreal injection of triamcinolone acetonide in age-related macular degeneration. Indian J Ophthalmol 2007;55:207211.

147 Chaudhary V, Mao A, Hooper PL, Sheidow TG: Triamcinolone acetonide as adjunctive treatment to verteporfin in neovascular age-related macular degeneration: a prospective randomized trial. Ophthalmology 2007; 114:2183-2189.

148 Iwama D, Otani A, Sasahara M, et al: Photodynamic therapy combined with lowdose intravitreal triamcinolone acetonide for age-related macular degeneration refractory to photodynamic therapy alone. $\mathrm{Br}$ J Ophthalmol 2008;92:1352-1356. 
-149 Frimpong-Boateng A, Bunse A, Rüfer F, Roider J: Photodynamic therapy with intravitreal application of triamcinolone acetonide in age-related macular degeneration: functional results in 54 patients. Acta Ophthalmol 2009;87:183-187.

150 Weigert G, Michels S, Saçu S, et al: Intravitreal bevacizumab (Avastin) therapy versus photodynamic therapy plus intravitreal triamcinolone for neovascular age-related macular degeneration: 6-month results of a prospective, randomised, controlled clinical study. Br J Ophthalmol 2008;92:356360 .

-151 Gamulescu MA, Schubert K, Thormann S, et al: ITAP: 6-month results of a prospective, randomised phase 3 study for evaluation of the combination therapy of PDT and intravitreal triamcinolone in exudative AMD (in German). Klin Monbl Augenheilkd 2009;226:60-65.

- 152 Jonas JB, Spandau UH, Harder B, Vossmerbaeumer U, Kamppeter BA: Intereye difference in exudative age-related macular degeneration with minimally classic or occult subfoveal neovascularization after unilateral intravitreal injection of triamcinolone acetonide. Am J Ophthalmol 2005;139: 1073-1079.

153 Potter MJ, Szabo SM, Ho T: Combined photodynamic therapy and intravitreal triamcinolone for the treatment of myopic choroidal neovascularization in a 13-year-old girl. Graefes Arch Clin Exp Ophthalmol 2006;244:639-641.

154 Degenring RF, Jonas JB: Photodynamic therapy in combination with intravitreal triamcinolone for myopic choroidal neovascularization. Acta Ophthalmol Scand 2005;83:621.

-155 Rechtman E, Allen VD, Danis RP, et al: Intravitreal triamcinolone for choroidal neovascularization in ocular histoplasmosis syndrome. Am J Ophthalmol 2003;136: 739-741.

156 Jonas JB, Hayler JK, Panda-Jonas S: Intravitreal injection of crystalline cortisone as treatment of pre-phthisical ocular hypotony. Graefes Arch Clin Exp Ophthalmol 2001;239:464-465.

-157 Rodriguez ML, Juarez CP, Luna JD: Intravitreal triamcinolone acetonide injection in blind painful eyes: intraocular steroids as a treatment for blind painful red eyes. Eur J Ophthalmol 2003;13:292-297.

-158 Heras-Mulero H, García-Layana A, Fernández-Hortelano A, García-Gómez PJ, Sádaba-Echarri LM: Silicone oil hypotonic maculopathy treatment (in Spanish). Arch Soc Esp Oftalmol 2005;80:417-420.

159 Young S, Larkin G, Branley M, Lightman S: Safety and efficacy of intravitreal triamcinolone for cystoid macular oedema in uveitis. Clin Experiment Ophthalmol 2001;29: $2-6$.
160 Benítez del Castillo Sánchez JM, García Sánchez J: Intravitreal injection of triamcinolone acetonide in non-infectious uveitis (in Spanish). Arch Soc Esp Oftalmol 2001;76:661-664.

161 Martidis A, Duker JS, Puliafito CA: Intravitreal triamcinolone for refractory cystoid macular edema secondary to birdshot retinochoroidopathy. Arch Ophthalmol 2001; 119:1380-1383

162 Antcliff RJ, Spalton DJ, Stanford MR, et al: Intravitreal triamcinolone for uveitic cystoid macular edema: an optical coherence tomography study. Ophthalmology 2001; 108:765-772

163 Degenring RF, Jonas JB: Intravitreal injection of triamcinolone acetonide as treatment for chronic uveitis. Br J Ophthalmol 2003;87:361.

164 Sonoda KH, Enaida H, Ueno A, et al: Pars plana vitrectomy assisted by triamcinolone acetonide for refractory uveitis: a case series study. Br J Ophthalmol 2003;87:1010-1014.

165 Andrade RE, Muccioli C, Farah ME, Nussenblatt RB, Belfort R Jr: Intravitreal triamcinolone in the treatment of serous retinal detachment in Vogt-Koyanagi-Harada syndrome. Am J Ophthalmol 2004;137: 572-574

166 Angunawela RI, Heatley CJ, Williamson $\mathrm{TH}$, et al: Intravitreal triamcinalone acetonide for refractory uveitic cystoid macular oedema: long-term management and outcome. Acta Ophthalmol Scand 2005;83: 595-599.

167 Larsson J, Hvarfner C, Skarin A: Intravitreal triamcinolone in two patients with refractory macular oedema in sarcoid uveitis. Acta Ophthalmol Scand 2005;83:618-619.

168 Marullo M, Perilli R, Balestrazzi E: Intravitreal triamcinolone in cystoid macular edema due to uveitis and repeated surgery after a penetrating trauma. Eur J Ophthalmol 2004; 14:581-583.

169 Benhamou N, Massin P, Haouchine B, et al: Intravitreal triamcinolone for refractory pseudophakic macular edema. Am J Ophthalmol 2003;135:246-249.

170 Conway MD, Canakis C, Livir-Rallatos C, Peyman GA: Intravitreal triamcinolone acetonide for refractory chronic pseudophakic cystoid macular edema. J Cataract Refract Surg 2003;29:27-33.

171 Karaçorlu M, Özdemir H, Karaçorlu S: Intravitreal triamcinolone acetonide for the treatment of chronic pseudophakic cystoid macular oedema. Acta Ophthalmol Scand 2003;81:648-652.

172 Boscia F, Furino C, Dammacco R, et al: In travitreal triamcinolone acetonide in refractory pseudophakic cystoid macular edema: functional and anatomic results. Eur J Ophthalmol 2005;15:89-95.
173 Chen SD, Lochhead J, McDonald B, Patel CK: Pseudohypopyon after intravitreal triamcinolone injection for the treatment of pseudophakic cystoid macular oedema. $\mathrm{Br}$ J Ophthalmol 2004;88:843-844.

174 Jonas JB, Kreissig I, Degenring RF: Intravitreal triamcinolone acetonide for pseudophakic cystoid macular edema. Am J Ophthalmol 2003;136:384-386.

175 Jonas JB: Intravitreal triamcinolone acetonide for treatment of sympathetic ophthalmia. Am J Ophthalmol 2004;137:367368.

176 Jonas JB, Spandau UH: Repeated intravitreal triamcinolone acetonide for chronic sympathetic ophthalmia. Acta Ophthalmol Scand 2006;84:436.

177 Özdemir H, Karaçorlu M, Karaçorlu S: Intravitreal triamcinolone acetonide in sympathetic ophthalmia. Graefes Arch Clin Exp Ophthalmol 2005;243:734-736.

178 Sutter FK, Gillies MC: Intravitreal triamcinolone for radiation-induced macular edema. Arch Ophthalmol 2003;121:14911493.

179 Shields CL, Demirci H, Dai V, et al: Intravitreal triamcinolone acetonide for radiation maculopathy after plaque radiotherapy for choroidal melanoma. Retina 2005; 25:868-874.

180 Jonas JB: Intravitreal triamcinolone for treatment of chronic focal immunological corneal graft reaction. Graefes Arch Clin Exp Ophthalmol 2003;241:779-780.

181 Alldredge CD, Garretson BR: Intravitreal triamcinolone for the treatment of idiopathic juxtafoveal telangiectasis. Retina 2003;23:113-116.

182 Martínez JA: Intravitreal triamcinolone acetonide for bilateral acquired parafoveal telangiectasis. Arch Ophthalmol 2003;121: 1658-1659.

183 Smithen LM, Spaide RF: Photodynamic therapy and intravitreal triamcinolone for a subretinal neovascularization in bilateral idiopathic juxtafoveal telangiectasis. Am J Ophthalmol 2004;138:884-885.

184 Jonas JB, Kreissig I, Degenring RF: Intravitreal triamcinolone acetonide as treatment of ischemic ophthalmopathy. Eur J Ophthalmol 2003;13:575-576.

185 Klais CM, Spaide RF: Intravitreal triamcinolone acetonide injection in ocular ischemic syndrome. Retina 2004;24:459-461.

186 Jonas JB: Intravitreal triamcinolone acetonide as treatment for extensive exudative retinal detachment. Br J Ophthalmol 2004; 88:587-588

187 Özdemir H, Karaçorlu M, Karaçorlu S: Intravitreal triamcinolone acetonide for treatment of cystoid macular oedema in patients with retinitis pigmentosa. Acta Ophthalmol Scand 2005;83:248-251. 
188 Sallum JM, Farah ME, Saraiva VS: Treatment of cystoid macular edema related to retinitis pigmentosa with intravitreal triamcinolone acetonide: case report. Adv Exp Med Biol 2003;533:79-81.

189 Saraiva VS, Sallum JM, Farah ME: Treatment of cystoid macular edema related to retinitis pigmentosa with intravitreal triamcinolone acetonide. Ophthalmic Surg Lasers Imaging 2003;34:398-400.

190 Rakic JM, Zelinkova M, ComhairePoutchinian Y, Galand A, Duchateau E: Treatment of Graves macular edema with intravitreal injection of corticosteroids (in French). Bull Soc Belge Ophtalmol 2003; 288:43-48.

191 Hogan A, Behan U, Kilmartin DJ: Outcomes after combination photodynamic therapy and immunosuppression for inflammatory subfoveal choroidal neovascularisation. Br J Ophthalmol 2005;89:11091111.

192 Inoue M, Nagai N, Shinoda H, et al: Intravitreal injection of triamcinolone acetonide for cystoid macular edema resistant to vitreous surgery (in Japanese). Nippon Ganka Gakkai Zasshi 2004;108:92-97.

- 193 Navajas EV, Costa RA, Farah ME, Cardillo JA, Bonomo PP: Indocyanine-green-mediated photothrombosis combined with intravitreal triamcinolone for the treatment of choroidal neovascularization in serpiginous choroiditis. Eye (Lond) 2003;17:563566.

194 Scott IU, Flynn HW Jr, Rosenfeld PJ: Intravitreal triamcinolone acetonide for idiopathic cystoid macular edema. Am J Oph thalmol 2003;136:737-739.

- 195 Jonas JB, Kamppeter BA: Intravitreal triamcinolone acetonide and central serous chorioretinopathy. Br J Ophthalmol 2005; 89:386-387.

196 Gharbiya M, Grandinetti F, Balacco Gabrieli C: Intravitreal triamcinolone for macular detachment following panretinal photocoagulation. Eye (Lond) 2005;19:818-820.

197 Jarin RR, Teoh SC, Lim TH: Resolution of severe macular oedema in adult Coats' syndrome with high-dose intravitreal triamcinolone acetonide. Eye (Lond) 2006;20: 163-165.

198 Jonas JB, Kamppeter B: Intravitreal triamcinolone acetonide for persisting cystoid macular edema after penetrating keratoplasty. Cornea 2006;25:240-241.

- 199 Karaçorlu M, Mudun B, Özdemir H, Karaçorlu SA, Bürümcek E: Intravitreal triamcinolone acetonide for the treatment of cystoid macular edema secondary to Behçet disease. Am J Ophthalmol 2004;138:289291.

200 Kramer M, Ehrlich R, Snir M, et al: Intravitreal injections of triamcinolone acetonide for severe vitritis in patients with incomplete Behçet's disease. Am J Ophthalmol 2004;138:666-667.
201 Kyto JP, Angerman S, Lumiste E, Paloheimo M, Summanen PA: Intravitreal triamcinolone acetonide as an adjuvant therapy to panretinal photocoagulation for proliferative retinopathy with high-risk characteristics in type 1 diabetes: case report with 22 weeks follow-up. Acta Ophthalmol Scand 2005;83:605-608.

202 Lahey JM, Kearney JJ, Cheung MC: Sequential treatment of central retinal vein occlusion with intravitreal tissue plasminogen activator and intravitreal triamcinolone. $\mathrm{Br}$ J Ophthalmol 2004;88:1100-1101.

203 Özdemir H, Karaçorlu M, Karaçorlu S: Resolution of foveal pseudocyst after intravitreal triamcinolone acetonide. Acta Ophthalmol Scand 2005;83:619-620.

204 Pathengay A, Pilli S, Das T: Intravitreal triamcinolone acetonide in Eales' disease: a case report. Eye (Lond) 2005;19:711-713.

205 Peiretti E, Klancnik JM Jr, Spaide RF, Yannuzzi L: Choroidal neovascularization in Sorsby fundus dystrophy treated with photodynamic therapy and intravitreal triamcinolone acetonide. Retina 2005;25:377379.

206 Wilson CA, Berkowitz BA, Sato Y, et al: Treatment with intravitreal steroid reduces blood-retinal barrier breakdown due to retinal photocoagulation. Arch Ophthalmol 1992;110:1155-1159.

207 Spaide RF, Fisher Y: Removal of adherent cortical vitreous plaques without removing the internal limiting membrane in the repair of macular detachments in highly myopic eyes. Retina 2005;25:290-295.

208 Peyman GA, Cheema R, Conway MD, Fang T: Triamcinolone acetonide as an aid to visualization of the vitreous and the posterior hyaloid during pars plana vitrectomy. Retina 2000;20:554-555.

209 Sakamoto T, Miyazaki M, Hisatomi T, et al: Triamcinolone-assisted pars plana vitrectomy improves the surgical procedures and decreases the postoperative blood-ocular barrier breakdown. Graefes Arch Clin Exp Ophthalmol 2002;240:423-429.

210 Burk SE, da Mata AP, Snyder ME, et al: Visualizing vitreous using Kenalog suspension. J Cataract Refract Surg 2003;29:645651.

211 Matsumoto H, Enaida H, Hisatomi T, et al: Retinal detachment in morning glory syndrome treated by triamcinolone-acetonideassisted pars plana vitrectomy. Retina 2003; 23:569-572.

212 Enaida H, Sakamoto T, Ueno A, et al: Submacular deposition of triamcinolone acetonide after triamcinolone-assisted vitrectomy. Am J Ophthalmol 2003;135:243-246.

-213 Takeuchi M, Katagiri Y, Usui M: Residual triamcinolone acetonide in the macular hole after vitrectomy. Am J Ophthalmol 2003;136:1174-1176.
214 Kimura H, Kuroda S, Nagata M: Triamcinolone-acetonide-assisted peeling of the internal limiting membrane. Am J Ophthalmol 2004;137:172-173.

215 Yamakiri K, Uchino E, Kimura K, Sakamoto $\mathrm{T}$ : Intracameral triamcinolone helps to visualize and remove the vitreous body in anterior chamber in cataract surgery. Am J Ophthalmol 2004;138:650-652.

216 Yamamoto N, Ozaki N, Murakami K: Triamcinolone acetonide facilitates removal of the epiretinal membrane and separation of the residual vitreous cortex in highly myopic eyes with retinal detachment due to a macular hole. Ophthalmologica 2004;218: 248-256.

217 Yamamoto N, Ozaki N, Murakami K: Double visualization using triamcinolone acetonide and trypan blue during stage 3 macular hole surgery. Ophthalmologica 2004; 218:297-305.

218 Satofuka S, Inoue M, Shinoda K, et al: Adherence of intravitreally injected triamcinolone acetonide to the denuded retinal surface after internal limiting membrane peeling. Retina 2005;25:672-673.

219 Chen TY, Yang CM, Liu KR: Intravitreal triamcinolone staining observation of residual undetached cortical vitreous after posterior vitreous detachment. Eye (Lond) 2006;20:423-427.

220 Karaçorlu M, Özdemir H, Arf Karaçorlu S: Does intravitreal-triamcinolone-acetonide-assisted peeling of the internal limiting membrane effect the outcome of macular hole surgery? Graefes Arch Clin Exp Ophthalmol 2005;243:754-757.

221 Jonas JB, Kreissig I, Budde WM, Degenring RF: Cataract surgery combined with intravitreal injection of triamcinolone acetonide. Eur J Ophthalmol 2005;15:329-335.

222 Scholes GN, O’Brien WJ, Abrams GW, Kubicek MF: Clearance of triamcinolone from vitreous. Arch Ophthalmol 1985;103:15671569.

223 Beer PM, Bakri SJ, Singh RJ, et al: Intraocular concentration and pharmacokinetics of triamcinolone acetonide after a single intravitreal injection. Ophthalmology 2003; 110:681-686.

224 Jonas JB: Concentration of intravitreally injected triamcinolone acetonide in intraocular silicone oil. Br J Ophthalmol 2002;86: 1450-1451.

225 Jonas JB: Concentration of intravitreally injected triamcinolone acetonide in aqueous humour. Br J Ophthalmol 2002;86:1066.

226 Gopal L, Sharma T: Use of intravitreal injection of triamcinolone acetonide in the treatment of age-related macular degeneration. Indian J Ophthalmol 2007;55:431435.

227 Zimmerman TJ, Kooner SK, Sharir M, et al: Textbook of Ocular Pharmacology. Philadelphia, Lippincott-Raven, 1997. 
228 Sobrin L, D’Amico DJ: Controversies in intravitreal triamcinolone acetonide use. Int Ophthalmol Clin 2005;45:133-141.

-229 Jermak CM, Dellacroce JT, Heffez J, Peyman GA: Triamcinolone acetonide in ocular therapeutics. Surv Ophthalmol 2007;52: 503-522.

-230 Oishi M, Maeda S, Hashida N, et al: Pharmacokinetic behavior of intravitreal triamcinolone acetonide prepared by a hospital pharmacy. Jpn J Ophthalmol 2008;52:489492.

-231 Albini TA, Abd-El-Barr MM, Carvounis $\mathrm{PE}$, et al: Long-term retinal toxicity of intravitreal commercially available preserved triamcinolone acetonide (Kenalog) in rabbit eyes. Invest Ophthalmol Vis Sci 2007;48: 390-395.

-232 Dierks D, Lei B, Zhang K, Hainsworth DP: Electroretinographic effects of an intravitreal injection of triamcinolone in rabbit retina. Arch Ophthalmol 2005;123:15631569.

-233 Ruiz-Moreno JM, Montero JA, Bayon A, Rueda J, Vidal M: Retinal toxicity of intravitreal triamcinolone acetonide at high doses in the rabbit. Exp Eye Res 2007;84: 342-348.

-234 McGee DH, Dembinska O, Gruebbel MM: Evaluation of triamcinolone acetonide following intravitreal injection in New Zealand white rabbits. Int J Toxicol 2005;24: 419-425.

-235 Kivilçim M, Peyman GA, El-Dessouky ES, et al: Retinal toxicity of triamcinolone acetonide in silicone-filled eyes. Ophthalmic Surg Lasers 2000;31:474-478.

236 Birinçi H: Surgical results of triamcinolone-assisted pars plana vitrectomy combined with phacoemulsification in diabetic patients. Open Ophthalmol J 2008;2:5-8.

-237 Hernández-da Mota SE, Chacón-Lara A, Hernández-Vázquez E: Use of triamcinolone and bevacizumab in 25 -gram phacovitrectomy surgery for the treatment of cataract and diabetic macular edema (in Spanish). Arch Soc Esp Oftalmol 2008;83: 293-300.

>238 Jaissle GB, Bartz-Schmidt KU, Szurman P: Optic atrophy subsequent to epiretinal triamcinolone deposits in an eye following inner limiting membrane peeling (in German). Ophthalmologe 2008;105:575-577.

-239 Hauser D, Bukelman A, Pokroy R, et al: Intravitreal triamcinolone for diabetic macular edema: comparison of 1,2, and $4 \mathrm{mg}$. Retina 2008;28:825-830.

-240 Audren F, Lecleire-Collet A, Erginay A, et al: Intravitreal triamcinolone acetonide for diffuse diabetic macular edema: phase 2 trial comparing $4 \mathrm{mg}$ versus $2 \mathrm{mg}$. Am J Ophthalmol 2006;142:794-799.
241 Lam DS, Chan CK, Mohamed S, et al: A prospective randomised trial of different doses of intravitreal triamcinolone for diabetic macular oedema. Br J Ophthalmol 2007;91:199-203

242 Shimura M, Nakazawa T, Yasuda K, et al: Comparative therapy evaluation of intravitreal bevacizumab and triamcinolone acetonide on persistent diffuse diabetic macular edema. Am J Ophthalmol 2008; 145:854-861

243 Diabetic Retinopathy Clinical Research Network, Beck RW, Edwards AR, Aiello LP, Bressler NM, Ferris F, Glassman AR, Hartnett E, Ip MS, Kim JE, Kollman C: Threeyear follow-up of a randomized trial comparing focal/grid photocoagulation and intravitreal triamcinolone for diabetic macular edema. Arch Ophthalmol 2009; 127:245-251.

244 Diabetic Retinopathy Clinical Research Network: A randomized trial comparing intravitreal triamcinolone acetonide and focal/grid photocoagulation for diabetic macular edema. Ophthalmology 2008;115: 1447-1449, 1449.e1-1449.e10.

-245 Sivaprasad S, Ockrim Z, Massaoutis P, et al: Posterior hyaloid changes following intravitreal triamcinolone and macular laser for diffuse diabetic macular edema. Retina 2008;28:1435-1442.

246 Lam DS, Chan CK, Mohamed S, et al: Intravitreal triamcinolone plus sequential grid laser versus triamcinolone or laser alone for treating diabetic macular edema: sixmonth outcomes. Ophthalmology 2007; 114:2162-2167.

247 Kim YM, Chung EJ, Byeon SH, et al: Pars plana vitrectomy with internal limiting membrane peeling compared with intravitreal triamcinolone injection in the treatment of diabetic macular edema. Ophthalmologica 2009;223:17-23.

248 Faghihi H, Roohipoor R, Mohammadi SF, et al: Intravitreal bevacizumab versus combined bevacizumab-triamcinolone versus macular laser photocoagulation in diabetic macular edema. Eur J Ophthalmol 2008;18: 941-948.

249 Joussen AM, Weiss C, Bauer D, Hilgers RD: Triamcinolone versus inner-limiting membrane peeling in persistent diabetic macular edema (TIME study): design issues and implications. Graefes Arch Clin Exp Ophthalmol 2007;245:1781-1787.

250 Jonas JB, Kreissig I, Degenring RF: Retinal complications of intravitreal injections of triamcinolone acetonide. Graefes Arch Clin Exp Ophthalmol 2004;242:184-185.

251 Bardak Y, Cekiç O, Tig SU: Comparison of ICG-assisted ILM peeling and triamcinolone-assisted posterior vitreous removal in diffuse diabetic macular oedema. Eye (Lond) 2006;20:1357-1359.
252 Riese J, Loukopoulos V, Meier C, Timmermann M, Gerding H: Combined intravitreal triamcinolone injection and laser photocoagulation in eyes with persistent macular edema after branch retinal vein occlusion. Graefes Arch Clin Exp Ophthalmol 2008;246:1671-1676.

253 Parodi MB, Iacono P, Ravalico G: Intravitreal triamcinolone acetonide combined with subthreshold grid laser treatment for macular oedema in branch retinal vein occlusion: a pilot study. Br J Ophthalmol 2008;92:1046-1050.

254 Chung EJ, Lee H, Koh HJ: Arteriovenous crossing sheathotomy versus intravitreal triamcinolone acetonide injection for treatment of macular edema associated with branch retinal vein occlusion. Graefes Arch Clin Exp Ophthalmol 2008;246:967-974.

255 Scott IU, Ip MS, VanVeldhuisen PC, et al: A randomized trial comparing the efficacy and safety of intravitreal triamcinolone with standard care to treat vision loss associated with macular edema secondary to branch retinal vein occlusion: the Standard Care versus Corticosteroid for Retinal Vein Occlusion (SCORE) study report 6. Arch Ophthalmol 2009;127:1115-1128.

256 Carroll LA, Hanasono MM, Mikulec AA, Kita M, Koch RJ: Triamcinolone stimulates bFGF production and inhibits TGF- $\beta 1$ production by human dermal fibroblasts. Dermatol Surg 2002;28:704-709.

257 Ciulla TA, Criswell MH, Danis RP, et al: Choroidal neovascular membrane inhibition in a laser-treated rat model with intraocular sustained-release triamcinolone acetonide microimplants. Br J Ophthalmol 2003;87:1032-1037.

258 Ciulla TA, Criswell MH, Danis RP, Hill TE: Intravitreal triamcinolone acetonide inhibits choroidal neovascularization in a lasertreated rat model. Arch Ophthalmol 2001; 119:399-404

259 Danis RP, Bingaman DP, Yang Y, Ladd B: Inhibition of preretinal and optic nerve head neovascularization in pigs by intravitreal triamcinolone acetonide. Ophthalmology 1996;103:2099-2104.

260 Folkman J, Ingber DE: Angiostatic steroids: method of discovery and mechanism of action. Ann Surg 1987;206:374-383.

261 Gao H, Qiao X, Gao R, et al: Intravitreal triamcinolone does not alter basal vascular endothelial growth factor mRNA expression in rat retina. Vision Res 2004;44:349356.

262 Penfold PL, Wen L, Madigan MC, et al: Triamcinolone acetonide modulates permeability and intercellular adhesion molecule-1 (ICAM-1) expression of the ECV304 cell line: implications for macular degeneration. Clin Exp Immunol 2000;121:458465. 
263 Penfold PL, Wen L, Madigan MC, King NJ, Provis JM: Modulation of permeability and adhesion molecule expression by human choroidal endothelial cells. Invest Ophthalmol Vis Sci 2002;43:3125-3130.

264 Penfold PL, Wong JG, Gyory J, Billson FA: Effects of triamcinolone acetonide on microglial morphology and quantitative expression of MHC-II in exudative age-related macular degeneration. Clin Experiment Ophthalmol 2001;29:188-192.

-265 Penn JS, Rajaratnam VS, Collier RJ, Clark AF: The effect of an angiostatic steroid on neovascularization in a rat model of retinopathy of prematurity. Invest Ophthalmol Vis Sci 2001;42:283-290.

266 Wang YS, Friedrichs U, Eichler W, Hoffmann S, Wiedemann P: Inhibitory effects of triamcinolone acetonide on bFGF-induced migration and tube formation in choroidal microvascular endothelial cells. Graefes Arch Clin Exp Ophthalmol 2002; 240:42-48.

-267 Wu WC, Cheng KC, Wu HJ: Intravitreal triamcinolone acetonide versus bevacizumab for treatment of macular oedema due to central retinal vein occlusion. Eye (Lond) 2009;23:2215-2222.

268 Tao Y, Hou J, Jiang YR, Li XX, Jonas JB: Intravitreal bevacizumab versus triamcinolone acetonide for macular oedema due to central retinal vein occlusion. Eye (Lond) 2009, E-pub ahead of print.

-269 Ip MS, Scott IU, VanVeldhuisen PC, et al: A randomized trial comparing the efficacy and safety of intravitreal triamcinolone with observation to treat vision loss associated with macular edema secondary to central retinal vein occlusion: the Standard Care versus Corticosteroid for Retinal Vein Occlusion (SCORE) study report 5. Arch Ophthalmol 2009;127:1101-1114.

-270 Jonas JB, Hayler JK, Sofker A, Panda-Jonas $S$ : Intravitreal injection of crystalline cortisone as adjunctive treatment of proliferative diabetic retinopathy. Am J Ophthalmol 2001;131:468-471.

-271 Das-Bhaumik RG, Jones NP: Low-dose intraocular triamcinolone injection for intractable macular oedema and inflammation in patients with uveitis. Eye 2006;20: 934-937.

-272 Chan WM, Lim E, Liu DT, Law RW, Lam DS: Intravitreal triamcinolone acetonide for choroidal granuloma in sarcoidosis. Am J Ophthalmol 2005;139:1116-1118.

273 Androudi S, Letko E, Meniconi M, et al: Safety and efficacy of intravitreal triamcinolone acetonide for uveitic macular edema. Ocul Immunol Inflamm 2005;13:205-212.

-274 Pathengay A: Intravitreal triamcinolone acetonide in serpiginous choroidopathy. Indian J Ophthalmol 2005;53:77-79.
275 Shah A, Branley M: Use of intravitreal triamcinolone in the management of birdshot retinochoroidopathy associated with cystoid macular oedema: a case study over a three-year period. Clin Experiment Ophthalmol 2005;33:442-444.

276 Kaynak S, Çelik L, Koçak N, et al: Staining of vitreous with triamcinolone acetonide in retained lens surgery with phacofragmentation. J Cataract Refract Surg 2006;32:5659.

277 Reinhard T, Sundmacher R: Adjunctive intracameral application of corticosteroids in patients with endothelial immune reactions after penetrating keratoplasty: a pilot study. Transpl Int 2002;15:81-88.

278 Benz MS, Murray TG, Dubovy SR, Katz RS, Eifrig CW: Endophthalmitis caused by $M y$ cobacterium chelonae abscessus after intravitreal injection of triamcinolone. Arch Ophthalmol 2003;121:271-273.

279 Jonas JB, Bleyl U: Morphallaxia-like ocular histology after intravitreal triamcinolone acetonide. Br J Ophthalmol 2004;88:839840.

280 Jonas JB, Kreissig I, Degenring RF: Endophthalmitis after intravitreal injection of triamcinolone acetonide. Arch Ophthalmol 2003;121:1663-1664.

281 Jonas JB, Kreissig I, Spandau UH, Harder B: Infectious and noninfectious endophthalmitis after intravitreal high-dosage triamcinolone acetonide. Am J Ophthalmol 2006;141:579-580.

282 Kreissig I, Degenring RF, Jonas JB: Intravitreal triamcinolone acetonide complication of infectious and sterile endophthalmitis (in German). Ophthalmologe 2006;103:3034.

283 Moshfeghi DM, Kaiser PK, Scott IU, et al: Acute endophthalmitis following intravitreal triamcinolone acetonide injection. Am J Ophthalmol 2003;136:791-796.

284 Nelson ML, Tennant MT, Sivalingam A, et al: Infectious and presumed noninfectious endophthalmitis after intravitreal triamcinolone acetonide injection. Retina 2003; 23:686-691.

285 Parke DW: Intravitreal triamcinolone and endophthalmitis. Am J Ophthalmol 2003; 136:918-919.

286 Westfall AC, Osborn A, Kuhl D, et al: Acute endophthalmitis incidence: intravitreal triamcinolone. Arch Ophthalmol 2005;123: 1075-1077.

287 Bucher RS, Hall E, Reed DM, et al: Effect of intravitreal triamcinolone acetonide on susceptibility to experimental bacterial endophthalmitis and subsequent response to treatment. Arch Ophthalmol 2005;123: 649-653.

288 Bucher RS, Johnson MW: Microbiologic studies of multiple-dose containers of triamcinolone acetonide and lidocaine hydrochloride. Retina 2005;25:269-271.
289 Amato JE, Lee DH, Santos BA, Akduman L: Steroid hypopyon following intravitreal triamcinolone acetonide injection in a pseudophakic patient. Ocul Immunol Inflamm 2005;13:245-247.

290 Garay-Aramburu G, Bilbao-Urtiaga A, Cuesta-García M, Larrauri-Arana A: A case of triamcinolone-induced pseudo-endophthalmitis after vitrectomy (in Spanish). Arch Soc Esp Oftalmol 2005;80:615-617.

-291 Moshfeghi AA, Scott IU, Flynn HW Jr, Puliafito CA: Pseudohypopyon after intravitreal triamcinolone acetonide injection for cystoid macular edema. Am J Ophthalmol 2004;138:489-492.

292 Sutter FK, Gillies MC: Pseudo-endophthalmitis after intravitreal injection of triamcinolone. Br J Ophthalmol 2003;87:972974.

293 Agrawal S, Agrawal J, Agrawal TP: Vitrectomy as a treatment for elevated intraocular pressure following intravitreal injection of triamcinolone acetonide. Am J Ophthalmol 2004;138:679-680.

294 Bakri SJ, Beer PM: The effect of intravitreal triamcinolone acetonide on intraocular pressure. Ophthalmic Surg Lasers Imaging 2003;34:386-390.

295 Bui Quoc E, Bodaghi B, Adam R, et al: Intraocular pressure elevation after subtenon injection of triamcinolone acetonide during uveitis (in French). J Fr Ophtalmol 2002; 25:1048-1056.

296 Chan CK, Fan DS, Chan WM, et al: Ocularhypertensive response and corneal endothelial changes after intravitreal triamcinolone injections in Chinese subjects: a 6-month follow-up study. Eye (Lond) 2005; 19:625-630.

297 Detry-Morel M, Escarmelle A, Hermans I: Refractory ocular hypertension secondary to intravitreal injection of triamcinolone acetonide. Bull Soc Belge Ophtalmol 2004: $45-51$.

298 Gillies MC, Kuzniarz M, Craig J, et al: Intravitreal-triamcinolone-induced elevated intraocular pressure is associated with the development of posterior subcapsular cataract. Ophthalmology 2005;112:139-143.

299 Gillies MC, Simpson JM, Billson FA, et al: Safety of an intravitreal injection of triamcinolone: results from a randomized clinical trial. Arch Ophthalmol 2004;122:336340.

300 Jonas JB, Degenring RF, Kreissig I, Akkoyun I, Kamppeter BA: Intraocular pressure elevation after intravitreal triamcinolone acetonide injection. Ophthalmology 2005;112:593-598.

-301 Jonas JB, Kreissig I, Degenring R: Intraocular pressure after intravitreal injection of triamcinolone acetonide. $\mathrm{Br} \mathrm{J}$ Ophthalmol 2003;87:24-27. 
-302 Jonas JB, Kreissig I, Degenring R: Secondary chronic open-angle glaucoma after intravitreal triamcinolone acetonide. Arch Ophthalmol 2003;121:729-730.

-303 Özkiris A, Erkiliç K: Complications of intravitreal injection of triamcinolone acetonide. Can J Ophthalmol 2005;40:63-68.

304 Park HY, Yi K, Kim HK: Intraocular pressure elevation after intravitreal triamcinolone acetonide injection. Korean J Ophthalmol 2005; 19:122-127.

>305 Singh IP, Ahmad SI, Yeh D, et al: Early rapid rise in intraocular pressure after intravitreal triamcinolone acetonide injection. Am J Ophthalmol 2004;138:286-287.

-306 Smithen LM, Ober MD, Maranan L, Spaide RF: Intravitreal triamcinolone acetonide and intraocular pressure. Am J Ophthalmol 2004;138:740-743.

\$307 Becker B, Bresnick G, Chevrette L, et al: Intraocular pressure and its response to topical corticosteroids in diabetes. Arch Ophthalmol 1966;76:477-483.

-308 Jonas JB, Degenring R, Kreissig I, Akkoyun I: Safety of intravitreal high-dose reinjections of triamcinolone acetonide. Am J Ophthalmol 2004;138:1054-1055.

-309 Jaissle GB, Szurman P, Bartz-Schmidt KU: Ocular side effects and complications of intravitreal triamcinolone acetonide injection (in German). Ophthalmologe 2004; 101:121-128.

-310 Macky TA, Oelkers C, Rix U, et al: Synthesis, pharmacokinetics, efficacy, and rat retinal toxicity of a novel mitomycin C-triamcinolone acetonide conjugate. J Med Chem 2002;45:1122-1127.

-311 Çekiç O, Chang S, Tseng JJ, et al: Cataract progression after intravitreal triamcinolone injection. Am J Ophthalmol 2005;139: 993-998.
312 Jonas JB, Degenring R, Vossmerbauemer U, Kamppeter B: Frequency of cataract surgery after intravitreal injection of highdosage triamcinolone acetonide. Eur J Ophthalmol 2005;15:462-464.

- 313 Bouzas EA, Karadimas P, Pournaras CJ: Central serous chorioretinopathy and glucocorticoids. Surv Ophthalmol 2002;47: 431-448.

314 Haimovici R, Koh S, Gagnon DR, Lehrfeld T, Wellik S: Risk factors for central serous chorioretinopathy: a case-control study. Ophthalmology 2004;111:244-249.

315 Kai W, Yanrong J, Xiaoxin L: Vehicle of triamcinolone acetonide is associated with retinal toxicity and transient increase of lens density. Graefes Arch Clin Exp Ophthalmol 2006;244:1152-1159.

316 Macky TA, Helmy D, El Shazly N: Retinal toxicity of triamcinolone's vehicle (benzyl alcohol): an electrophysiologic and electron microscopic study. Graefes Arch Clin Exp Ophthalmol 2007;245:817-824.

317 Lang Y, Zemel E, Miller B, Perlman I: Retinal toxicity of intravitreal Kenalog in albino rabbits. Retina 2007;27:778-788.

-318 Tokuda K, Tsukamoto T, Fujisawa S, Matsubara M: Evaluation of toxicity due to vita stains in isolated rat retinas. Acta Ophthalmol Scand 2004;82:189-194

319 Degenring RF, Jonas JB: Serum levels of triamcinolone acetonide after intravitreal injection. Am J Ophthalmol 2004;137:11421143.

320 Yeung CK, Chan KP, Chan CK, Pang CP, Lam DS: Cytotoxicity of triamcinolone on cultured human retinal pigment epithelial cells: comparison with dexamethasone and hydrocortisone. Jpn J Ophthalmol 2004;48: 236-242.
321 Yeung CK, Chan KP, Chiang SW, Pang CP, Lam DS: The toxic and stress responses of cultured human retinal pigment epithelium (ARPE19) and human glial cells (SVG) in the presence of triamcinolone. Invest Ophthalmol Vis Sci 2003;44:5293-5300.

322 Mora P, Eperon S, Felt-Baeyens O, et al: Trans-scleral diffusion of triamcinolone acetonide. Curr Eye Res 2005;30:355-361.

323 Okubo A, Ito M, Kamisasanuki T, Sakamoto T: Visual improvement following transTenon retrobulbar triamcinolone acetonide infusion for polypoidal choroidal vasculopathy. Graefes Arch Clin Exp Ophthalmol 2005;243:837-839.

324 Tunc M, Onder HI, Kaya M: Posterior subTenon capsule triamcinolone injection combined with focal laser photocoagulation for diabetic macular edema. Ophthalmology 2005;112:1086-1091.

325 dal Canto AJ, Downs-Kelly E, Perry JD: Ptosis and orbital fat prolapse after posterior sub-Tenon capsule triamcinolone injection. Ophthalmology 2005;112:10921097.

326 Hernáez-Ortega MC, Soto-Pedre E: A simple and rapid method for purification of triamcinolone acetonide suspension for intravitreal injection. Ophthalmic Surg Lasers Imaging 2004;35:350-351.

327 Oishi M, Maeda S, Nakamura A, et al: Examination of purification methods and development of intravitreal injection of triamcinolone acetonide. Jpn J Ophthalmol 2005;49:384-387.

328 Aiello LP, Brucker AJ, Chang S, et al: Evolving guidelines for intravitreous injections. Retina 2004;24:S3-S19.

329 Blumenkranz MS, Claflin A, Hajek AS: Selection of therapeutic agents for intraocular proliferative disease: cell culture evaluation. Arch Ophthalmol 1984;102:598-604. 